\title{
The serial verb construction in Chinese: A tenacious myth and a Gordian knot $^{1}$
}

\author{
WALTRAUD PAUL
}

\begin{abstract}
The term "construction" is not a label to be assigned randomly, but presupposes a structural analysis with an associated set of syntactic and semantic properties. Based on this premise, the term "serial verb construction" (SVC) as currently used in Chinese linguistics will be shown to simply refer to any multiverb surface string i.e,. to subsume different constructions. The synchronic consequence of this situation is that SVCs in Chinese linguistics are not commensurate with SVCs in, e.g., Niger-Congo languages, whence the futility at this stage to search for a "serialization parameter" deriving the differences between so-called "serializing" and "non-serializing" languages. On the diachronic side, SVCs are invoked as a privileged site for verb-to-preposition reanalysis, but it is left open what structure is referred to under this label. A precise structural analysis of both the input and the output structure is, however, indispensable in order to make meaningful statements about language change.
\end{abstract}

\section{Introduction}

The basic assumption serving as the starting point of the present article is that the term construction is not a label to be assigned randomly. Instead, to talk of

\footnotetext{
1. This article is a substantially revised and extended version of work presented under the same or a similar title on different occasions in Gent, Paris, and Oxford over the past few years. I thank the audiences for feedback. I am especially indebted to two anonymous TLR reviewers for their insightful comments and suggestions which helped to improve both the content and the form of the article. I am equally grateful to Huba Bartos for his perseverance and patience as editor of this special issue. Last, but not least my thanks go to John Whitman who was exposed to the very first version of this article and whose critical remarks saved the future readers from getting lost in my meanderings through the conceptual labyrinth of SVCs.
} 
a construction implies that a precise structural analysis is available and that the syntactic and semantic properties associated with the structure at hand have been established. If these requirements are not met, it is futile to identify a given surface string as a "construction" $\mathrm{X}$, nor is it meaningful to compare this "construction" $\mathrm{X}$ across languages, the tertium comparationis not being guaranteed. The far-reaching consequences of such a loose application of the term "construction" will be illustrated by examining in detail the term serial verb "construction" as it is currently employed in Chinese linguistics.

I will demonstrate that in Chinese linguistics the term serial verb "construction" (SVC) simply refers to any surface string with more than one verb, i.e., it subsumes a multitude of different constructions in the sense outlined above. Accordingly, the bi-unique relationship between term and concept as required in any technical terminology is not given here, although this is the very basis for communication within a specialized field.

Similarly, in African linguistics (Niger-Congo languages), the term SVC also denotes a variety of different constructions, notwithstanding the consensus that a SVC is not a coordinate structure, that it denotes a single (composite) event and presents one clausal domain.

This state of affairs has two important consequences, both for synchronic and for diachronic studies. The synchronic consequence is that SVCs in Chinese linguistics are not commensurate with, e.g., SVCs in Niger-Congo languages, hence it is futile at the present stage to undertake typological studies aiming to derive the differences between so-called "serializing" and "non-serializing" languages in terms of a "serialization parameter". On the diachronic side, SVCs are invoked as a privileged site for numerous grammaticalization phenomena, but it is left completely open what structure is referred to under this label. In order to make meaningful statements about language change, however, it is indispensable to have a precise structural analysis of both the input and the output structure.

The article is organized as follows. Taking the different "definitions" of SVC proposed by Li and Thompson $(1981,1974,1973)$ as representative of the current practice in the field, Section 2 carefully examines them one by one and argues that in Chinese linguistics "SVC" has served as a cover term for distinct constructions with different properties; it does not refer to a unique construction with a predictable set of formal properties. Section 3 compares the situation in Chinese linguistics with that in Niger-Congo languages and concludes that there is hardly any overlap between the phenomena labeled SVC in each language (family). Section 4 discusses the crucial role assigned to SVC in both diachronic and typological studies. It demonstrates that the term SVC in diachronic syntax likewise serves as a cover term for any multi-verb sequence. Last, but not least, it illustrates how the indeterminacy of the term SVC may lead to an incorrect analysis of a language particular phenomenon as well as 
to wrong crosslinguistic generalizations. Given this state of affairs where no precise content is associated with the term SVC, the conclusion in Section 5 suggests a radical solution, i.e., to abandon the term SVC in its current usage in Chinese linguistics.

\section{The SVC and its "definitions" in Chinese linguistics: Li and Thomp- son $(1981,1974,1973)$}

It is important to note at the outset that I do not intend to give an overwiew of the abundant literature on SVCs here, nor do I claim to even attempt to do justice to the different conceptions of SVC present in the literature. ${ }^{2}$ Instead, I want to concentrate on the situation within Chinese linguistics where a large variety of completely different phenomena is subsumed under the unique label SVC. For expository purposes, I have chosen Li and Thompson's view of SVC as representative for the current practice in the field. Not only has their work been quite influential in Chinese linguistics and beyond, but at the same time it offers the advantage to be very explicit about the coverage of the term SVC. It thus allows us to address the issue in a way which has the advantage of being accessible to non-sinologists and of being more systematic than a collection of all the phenomena labeled SVC by different authors in the Chinese literature (cf. Li, Linding 1986: Ch. 14; Lü, Shuxiang 2000: 36ff.; Zhu, Dexi 1982: Ch. 12, inter alia). Importantly, taken together these views lead to as large a coverage of the term SVC as that defended in Li and Thompson.

In the following, I will first present $\mathrm{Li}$ and Thompson's point of view and then subject to a detailed scrutiny each of the phenomena claimed to instantiate an SVC. This at first sight tedious procedure is indispensable, because the failure in Chinese linguistics to systematically take stock of the entire range of phenomena labelled SVC, to provide an analysis for each phenomenon, and to evaluate the overall consequences resulting from the passepartout nature of the term SVC constitutes the main reason why its problematic character - if not its total uselessness - has largely gone unnoticed, also in formally oriented studies (cf. Section 2.3 below).

\subsection{Li and Thompson (1981)}

We will use the term serial verb construction to refer to a sentence that contains two or more verb phrases or clauses juxtaposed without any marker indicating

2. For comprehensive overviews within different frameworks, cf. Muysken and Veenstra (2006); Aikhenvald and Dixon (2006); Baker and Stewart (2002); Stewart (2001); Déchaine (1993); Lefebvre (1991); Bisang (1992), inter alia. 
what their relationship is between them. What this means is that in Mandarin there are many sentences that all have the same form, namely [...] (NP) V (NP) (NP) V (NP) but that convey different types of messages because of the meanings of the verbs involved and the relationships that are understood to hold between them. That is, the property they all share is that the verb phrases in the serial verb construction always refer to events or states of affairs which are understood to be related as parts of one overall event or state of affairs. The exact way in which they are related varies according to the meanings of the verbs in these verb phrases. (Li and Thompson 1981: 594).

Li and Thompson (1981) propose to distinguish four different types of SVC:

1st type: The SVC expresses "two or more separate events" (Li and Thompson 1981: 595; emphasis mine) and "may be understood to be related in one or more of the following four ways": (i) consecutive, (ii) purpose, (iii) alternating, (iv) circumstance:

$$
\begin{aligned}
& \text { Wŏmen kāi huì tăolùn nèi-ge wèntí. }{ }^{3} \\
& 1 \mathrm{PL} \text { hold meeting discuss that-CL problem } \\
& \text { 'We'll hold a meeting to discuss that problem.' (purpose) } \\
& \text { 'We'll discuss that problem holding a meeting.' (circumstance) }
\end{aligned}
$$

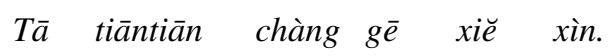

3SG every:day sing song write letter

'Every day she sings songs and writes letters.' (consecutive/alternating)

2nd type: "One verb phrase or clause is the subject or direct object of another verb" (p. 598).

(3) Tā fŏurèn tā zuò-cuò-le.

3SG deny $3 \mathrm{SG}$ do-err-PERF

'S/he denies that s/he was wrong.' (= Li and Thompson's (19))

(4) Tā gàosù wŏ nŭ tóu téng.

$3 \mathrm{SG}$ tell $1 \mathrm{SG} 2 \mathrm{SG}$ head ache

'S/he told me that you had a headache.' (= Li and Thompson's (37))

(5) Dàshēng niàn kèwén kĕy̆ bāngzhù fāyīn.

loud read lesson can help pronunciation

'Reading the lesson aloud can help one's pronunciation.' (= Li and Thompson's (42))

3. The following abbreviations are used in glossing examples: CL classifier; PERF 'perfective aspect'; NEG negation; PART sentence-final particle; PL plural (e.g., 3PL = 3rd person plural); SG singular; SUB subordinator. 


$$
\text { Xué Ménggŭhuà hĕn bù róngyì. }
$$

learn Mongolian very NEG easy

'It is not easy to learn Mongolian.' (= Li and Thompson's (43))

3rd type: The so-called pivotal construction where "a noun phrase [...] is simultaneously the subject of the second verb and the direct object of the first verb" (p. 607)

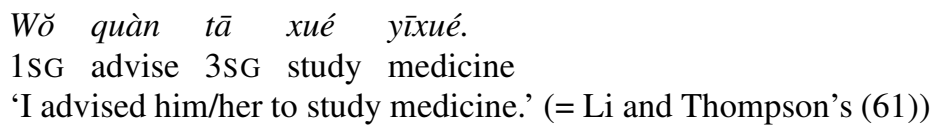

4th type: The so-called descriptive clause construction which "involves a transitive verb whose object is 'described' by a following clause" (p. 611):

$$
\begin{array}{lllll}
\text { Wŏ pèngdào-le yī-ge wàiguórén huì shuō Zhōngguóhuà. } \\
1 \mathrm{SG} \text { meet-PERF 1-CL foreigner can speak Chinese }
\end{array}
$$$$
\text { 'I met a foreigner who can speak Chinese.' (= Li and Thompson's }
$$

$$
\begin{array}{lllll}
T a \bar{a} & \text { chăo-le yi-ge cài tèbié } & \text { hăochī. } \\
\text { 1SG fry-PERF } & \text { 1-CL dish especially delicious }
\end{array}
$$

'He has prepared a dish which is particularly delicious.' (= $\mathrm{Li}$ and Thompson's (78) slightly modified)

A quick glance suffices to see that the preceding list represents quite a rich array of phenomena. ${ }^{4}$ In the following, I will demonstrate that in fact a range

4. Interestingly enough, the so-called directional verb compounds are one of the very few phenomena involving several verbs which have not been subsumed under SVC in the literature (but cf. Ernst 1989 and Law 1996 for a first attempt in this direction):

(i) Tā duān-le ȳ̄-wăn tāng shàng-lái le.

3SG serve-PERF 1-bowl soup ascend-come PART

'He served up a bowl of soup (towards the speaker).'

(ii) Tā duān-shàng-lái-le ȳ̄-wăn tāng le.

3SG serve-ascend-come-PERF 1-bowl soup PART

'He served up a bowl of soup (towards the speaker).'

As illustrated in (i), contrary to its denomination, the sequence ' $V_{\text {displacement }}\left(-V_{\text {direction }}\right)$ come/go' cannot be a compound; the first verb can be suffixed with the perfective aspect marker -le, and the object can occupy a position within the sequence. This is precisely excluded for verbal compounds such as [vopi-píng], 'criticize-judge' = 'criticize', [vo pāo-qì] 'throw-discard' = 'abandon', [v ${ }^{\circ}$ he-wán] 'drink-finish' = 'drink up' etc., given the Lexical Integrity Hypothesis (cf. Huang 1984b and references therein), which states that word-internal structure is inaccessible to syntactic processes. 


\section{$372 \quad$ Waltraud Paul}

of completely different constructions is subsumed under the unique label SVC here, thereby making the concept of SVC completely void. In other words, to "know" that a given multi-verb sequence is an SVC amounts to not knowing anything about the hierarchical relationship between the verbs (coordination of $\mathrm{V} 1$ and V2 vs. subordination of V1 to V2, or vice versa) and the associated interpretation.

Let us start with the first type where the SVC expresses two or more separate events and has four possible "interpretations": (i) circumstance, (ii) purpose, (iii) alternating, (iv) consecutive. A correction is immediately called for here: the so-called different "interpretations" in reality indicate the existence of different structures, i.e., the surface string in (10a) can be parsed in two different ways (for which evidence will be provided in (14)-(15) below). $\mathrm{VP}_{1}$ is either contained in an adjunct clause as in (10b) (leading to the "circumstance" interpretation) or it constitutes the matrix predicate as in (12) (leading to the "purpose" interpretation):

$$
\begin{aligned}
& \text { a. Wŏmen kāi huì tăolùn nèi-ge wèntí. (=(1) above) } \\
& \text { 1PL hold meeting discuss that-CL problem } \\
& \text { b. Wŏmen } \left.{ }_{\mathrm{i}}\left[{ }_{\nu \mathrm{P}} \text { [adjunct clause } P R O_{\mathrm{i}} \quad k \bar{a} i \quad h u i\right]\right] \quad\left[\begin{array}{ll}
{ }_{\nu} \mathrm{P} & \text { tăolùn }
\end{array}\right. \\
& 1 \mathrm{PL} \quad \text { hold meeting discuss } \\
& \text { nèi-ge wèntí]]. } \\
& \text { that-CL problem } \\
& \text { 'We'll discuss that problem holding a meeting.' }
\end{aligned}
$$

$$
\begin{aligned}
& \text { Wŏmen [ }{ }_{\mathrm{P}} \text { [adjunct míngtiān / zài xuéxiào / yīdìng] } \\
& \text { 1PL tomorrow / at school / certainly } \\
& \text { [vP tăolùn nèi-ge wèntí }] \text {. } \\
& \text { discuss that-CL problem }
\end{aligned}
$$

With kai hui 'hold a meeting' analyzed as a clause adjoined to the main VP and having an adverbial function, we obtain the structure and corresponding interpretation in (10b); the covert subject of the adjunct clause, noted as $P R O$,

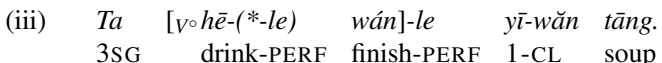
'He finished a bowl of soup.'
}

The sequences ' $\mathrm{V}_{\text {displacement }}\left(-\mathrm{V}_{\text {direction }}\right)$-come/go' have not received a satisfying analysis yet, in spite of the numerous studies devoted to them (cf. among others Fan, Jiyan 1963; Lu, John H.-T. 1973; Kimura 1984; Li, Linding 1984; Lu, Jianming 1985; Liu, Yuehua 1988; Chang, Hsun-Huei 1991; Zou, Ke 1994; Yang, Defeng 2004). For a new analysis in terms of an internal-argument sharing SVC à la Collins (1997) (cf. Section 3 below), see Paul (in preparation). 
is controlled by the matrix subject $t a$ 'he'. The structure of (10b) is thus on par with (11) where the main VP taolun nei-ge wenti 'discuss that problem' is modified by an adjunct NP, adjunct PP or adverb, respectively, rather than by a clause as in (10b). In the remainder of the article, I will refer to the structure illustrated in $(10 \mathrm{~b}),\left[\mathrm{S}_{\mathrm{i}}\left[v \mathrm{P}\right.\right.$ [adjunct clause $\left.\left.\left.P R O_{\mathrm{i}} \mathrm{VP}\right]\left[{ }_{\nu \mathrm{P}} \mathrm{V}(\mathrm{O})\right]\right]\right]$, as adjunct structure.

By contrast, in (12), it is kai hui 'hold the meeting' which is analyzed as the main VP and taolun nei-ge wenti 'discuss that problem' represents a purpose clause subordinate to the main VP:

$$
\begin{aligned}
& \text { Wŏmen }_{\mathrm{i}}{ }_{\text {v }} \quad k \bar{a} i \text { huì [purpose clause } P R O_{\mathrm{i}} \text { tăolùn nèi-ge } \\
& 1 \mathrm{PL} \text { hold meeting discuss that-CL } \\
& \text { wèntí]]. } \\
& \text { problem } \\
& \text { 'We'll hold a meeting to discuss that problem.' }
\end{aligned}
$$

Given that the subject is obligatorily covert and controlled by the matrix subject, the general consensus is that the purpose clause is non-finite. ${ }^{5}$ Furthermore, purpose clauses with a covert object (coreferential with the matrix object) in addition to the covert subject (cf. (13)) are in general analyzed as involving a null operator, whence the proposal that the purpose clause has the size of CP (cf., a.o., Huang 1984a and Tang 1990, whose analysis is adopted by Tsai 1995):

$$
\begin{aligned}
& T \bar{a}_{\mathrm{i}} \quad z h \check{u} \quad t \bar{a} n g_{\mathrm{j}} \quad\left[{ }_{\mathrm{CP}} O p_{\mathrm{j}}\left[\text { IIP }_{P R O_{\mathrm{i}}} h \bar{e} \quad t_{\mathrm{j}}\right] .\right. \\
& 3 \mathrm{SG} \text { cook soup drink } \\
& \text { 'He cooked soup to drink.' (Tang 1990: 297, (82)) }{ }^{6}
\end{aligned}
$$

(13) is thus analyzed on a par with English sentences such as I bought a book to read, modulo the introduction of the Generalized Control Rule (GCR) proposed by Huang (1984a: 552), extending Chomsky's (1980) rule of control to cover both pro and PRO. ${ }^{7}$ Importantly, as pointed out by Huang (1984: 569), the purpose clause is not an argument of the matrix verb, but rather a modifier or predicate, i.e., the purpose clause structure illustrated by sentences such as

5. For discussion of the finite vs. non-finite distinction in Mandarin Chinese, cf. Huang (1982); Li (1990); Ernst (1994); and Tang (2000), among others.

6. Note that according to Tang (1990: 300-301), control constructions are an instance of SVC: "[...] in Chinese serial verb constructions are control constructions and are in the form of [NP VP CP]." For Li and Thompson (1981: 618-620), a purpose clause structure with both a covert subject and object such as (13) illustrates a variant of the fourth type of SVC, which they label irrealis descriptive clause.

7. "Coindex an empty pronominal with the closest nominal element." (Huang 1984a: 552, (61)). 
(12) and (13), [ $\mathrm{S}_{\mathrm{i}}\left[{ }_{v \mathrm{P}} \mathrm{V}(\mathrm{O})\left[\mathrm{CP}\left[\mathrm{IP} P R O_{\mathrm{i}}\left[{ }_{\nu \mathrm{P}} \mathrm{V}(\mathrm{O})\right]\right]\right]\right]$, does not involve complementation. ${ }^{8}$

The difference between the adjunct structure, on the one hand, and the purpose clause structure, on the other, is e.g. reflected in the distribution of the perfective verb suffix -le. Since -le marks the main verb, (14a) and (15a) must be analyzed as adjunct structures and (14b) and (15b) as purpose clause structures: 9

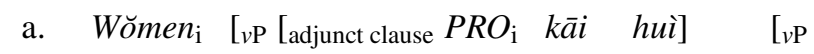
$1 \mathrm{PL} \quad$ hold meeting

tăolùn-le nèi-ge wèntí]].

discuss-PERF that-CL problem

'We have discussed that problem holding a meeting.'

b. Wŏmen ${ }_{\mathrm{i}}{ }_{\mathrm{v}}$ kāi-le san-ci huì $\quad\left[{ }_{\mathrm{CP}} P R O_{\mathrm{i}}\right.$ tăolùn $1 \mathrm{PL}$ hold-PERF 3-time meeting discuss nèi-ge wèntí]].

that-CL problem

'We held three meetings to discuss that problem.'
a. Tâ ${ }_{\nu \mathrm{P}}$ [adjunct clause $P R O_{\mathrm{i}}$ dă diànhuà] ${ }_{\nu \mathrm{P}}$ jiào-le 3SG strike phone call-PERF chē]] y̆hò̀u hái dĕng-le èrshífēnzhōng. car after still wait-PERF 20-minute 'After she had called a taxi by phone, she still waited for twenty minutes.'

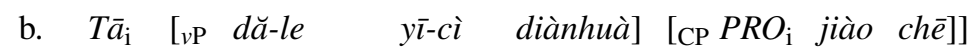
$3 \mathrm{SG}$ beat-PERF 1-time phone call car 'He made a phone call to order a taxi.'

c. Tā dă diànhuà jiào chē.

3SG strike phone call car

(i) 'He called a taxi by phone'

(ii) 'He made a phone call to order a taxi.' (Li, Linding 1986: 135)

8. Note that in the remainder of the article I will concentrate on the purpose clause structure with a covert subject only.

9. The boundedness of the event required by the perfective suffix -le can either be obtained by quantifying the object (as in (14b) and (15b), if it is not definite as in (14a)) or by embedding the clause in a complex sentence as in (15a). This explains why the examples illustrating the difference between the adjunct structure and the purpose clause structure do not constitute perfect minimal pairs. Also note that some of the native speakers consulted preferred the presence of lái 'in order to' preceding the purpose clause in (14b) and (15b). 
Note in passing that Li Linding himself observes the two different "interpretations" possible for (15c), but like $\mathrm{Li}$ and Thompson, he does not link the availability of different interpretations to the existence of different parsing possibilities. (For further discussion of the adjunct structure and the purpose clause structure, cf. Section 2.2 below.)

So far I have discussed the circumstance and purpose "interpretation" invoked by $\mathrm{Li}$ and Thompson for a sentence such as (10a) (repeated in (16a) below), and provided the corresponding structures, i.e., the adjunct structure and the purpose clause structure. Contrary to Li and Thompson's claim, such a sentence can precisely not be analyzed as a coordinate structure, giving rise to the "consecutive" or "alternating" interpretation. This is only possible when a pause occurs between the two VPs (16b) or in the presence of explicit marking by, e.g., adverbs (17a) (also cf. Chao 1968: 325-326; Li, Linding 1986: 132): ${ }^{10}$

$$
\begin{aligned}
& \text { a. Wŏmen kāi huì tăolùn nèi-ge (=(10a) above) } \\
& \text { 1PL hold meeting discuss that-CL } \\
& \text { wèntí. } \\
& \text { problem } \\
& \text { b. Wŏmen }\left[{ }_{\nu \mathrm{P}}\left[\begin{array}{lll}
{ }_{\nu} \mathrm{P} & k \bar{a} i & h u i
\end{array}\right], \quad\left[{ }_{\nu \mathrm{P}}\right. \text { tăolùn nèi-ge }\right. \\
& 1 \mathrm{PL} \quad \text { hold meeting discuss that-CL } \\
& \text { wèntí]]. } \\
& \text { problem } \\
& \text { 'We hold a meeting and discuss that problem.' }
\end{aligned}
$$

(17) a. Tā yzi-miàn pāi shŏu $\underline{y \overline{-}-m i a ̀ n}$ xiào.

3SG one-side clap hand one-side laugh

'He is clapping hands and laughing simultaneously.'

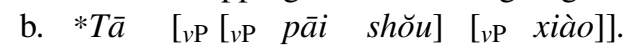

3SG clap hand laugh

(Intended meaning: 'He claps his hands and laughs.')

c. $\quad T \bar{a}_{\mathrm{i}} \quad\left[{ }_{\nu \mathrm{P}}\left[\right.\right.$ adjunct clause $P R O_{\mathrm{i}} \quad p \bar{a} i(-z h e)$ shŏu$] \quad\left[\begin{array}{ll}\nu_{\mathrm{P}} & x i a ̀ o\end{array}\right]$. $3 \mathrm{SG} \quad$ clap-DUR hand laugh 'He laughs (while) clapping his hands.'

10. Note in this context that Li and Thompson's (1981) example (2), repeated in (i) below, is not as "unmarked" as they pretend it to be. On the contrary, it is the presence of the adverb tiantian 'every day' in combination with a pause between the two VPs which makes it possible to analyze (i) as a coordinate structure and which furthermore favours the interpretation in terms of alternating actions (rather than as consecutive or simultaneous actions).

(i) Tā tiāntiān chàng gē xiĕ xìn.

3SG every:day sing song write letter

'Every day she sings songs and writes letters.' 
Importantly, as illustrated in (17b-c), an analysis in terms of a coordinate construction is precisely not a viable analysis for a sentence with two VPs lacking any overt marking. Instead, the sentence is parsed as an adjunct structure, which for some speakers necessitates the presence of the durative aspect suffix $-z h e$ in the adjunct clause (for further discussion, cf. Section 2.2 below).

The second type mentioned by $\mathrm{Li}$ and Thompson where "[o]ne verb phrase or clause is the subject or direct object of another verb" in fact groups together two different structures: one where $\mathrm{V}_{1}$ is contained in a sentential subject (cf. (18)-(21)) below) and one where $\mathrm{V}_{1}$ selects a complement clause (cf. (25)(26) below). These two structures not only differ from each other, but are also clearly distinct from the adjunct and the purpose clause structure discussed above; nonetheless, all four are claimed to instantiate SVC.

Let us first look at the sentential subject structure. As illustrated in (18)(21), the sentential subject constitutes a finite propositional domain of its own whose subject may be overt or covert $\left(\mathrm{PRO}_{\mathrm{arb}}\right)$ and which can be negated independently of the matrix predicate:

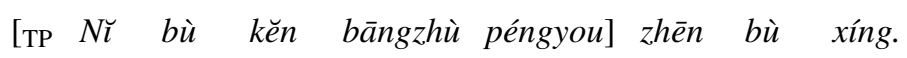
2SG NEG want help friend really NEG possible 'That you're not willing to help your friends is really not acceptable.'

$$
\begin{array}{lllllll}
\text { [тр } P R O_{\text {arb }} & z h \breve{l} & \text { tīng bù niàn] bù néng bāngzhù } \\
& \text { only listen NEG read NEG can help }
\end{array}
$$

fāyīn.

pronunciation

'Only listening without reading cannot help one's pronunciation.'

$$
\begin{aligned}
& {\left[\mathrm{TP} P R O_{\text {arb }}\right.} \text { zài zhèli tíng chē] bù wéizhāng. } \\
& \text { at here stop car NEG against:rules }
\end{aligned}
$$

'To park here is not against the rules.'

$$
\begin{array}{lllll}
\text { [TP } & \text { Tã méi lái] zhēn qíguài. } \\
\text { 3SG NEG come really strange }
\end{array}
$$

'That he hasn't come is really strange.'

This clearly contrasts with the adjunct structure where negation may only occur once and must precede the adjunct clause (cf. Tang 2000: 204; a.o.): ${ }^{11}$

11. This is not to say that the VP within the adjunct clause itself cannot be negated (cf. Teng 1974: 136). However, these cases (cf. (i)) require a clear context favouring such a parsing, because in general, negation preceding the adjunct clause is understoood as having matrix scope (thus including $v \mathrm{P}$-adjoined material):

(i)

$$
\begin{aligned}
& \text { Nimen }_{\mathrm{i}} \text { [ }{ }_{\nu \mathrm{P}} \text { [adjunct clause } P R O_{\mathrm{i}} \text { bu yong shou] }{ }_{{ }_{v} \mathrm{P}} \text { chi dangao]]. } \\
& \text { 2PL NEG use hand eat cake } \\
& \text { 'Eat the cake without using your hands.' (e.g., in a contest at a birthday party) }
\end{aligned}
$$




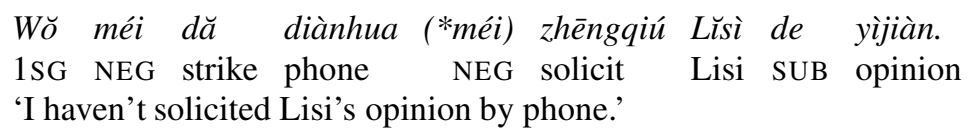

That in (18)-(21) the first verb is contained within a sentential subject is demonstrated by the unacceptability of A-not-A question (cf. Huang 1982) where the verb is juxtaposed with its negative counterpart (cf. (23c)). Huang (1981/82) shows that (23c) involves a subjacency violation in the same way as A-not-A questions in relative clauses and sentential topics. By contrast, $\mathrm{V}_{2}$, the matrix verb, can be questioned (cf. (23b)):

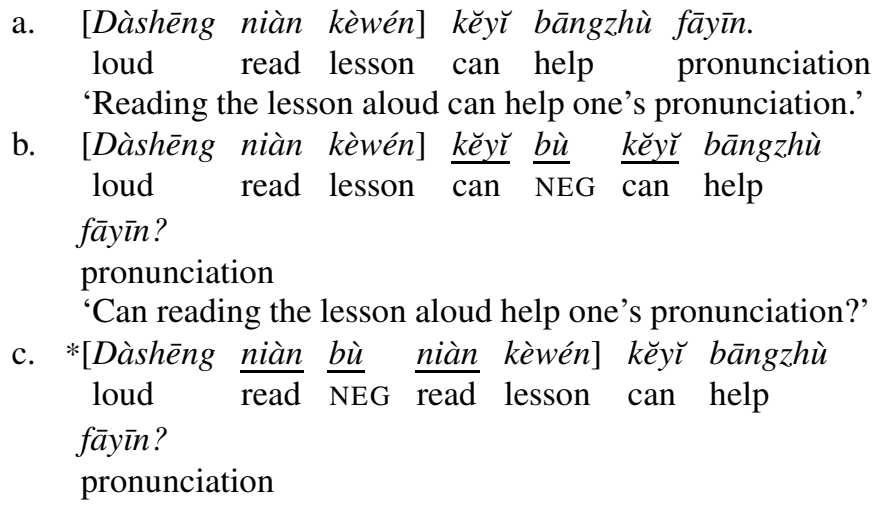

Example (24) finally illustrates that the verb within the sentential subject may be marked for aspect; in combination with the possibility of an overt subject (cf. (18), (21) above) this indicates the finite character of the propositional domain constituting the sentential subject:

$$
\begin{aligned}
& \text { [тP Tă qù(-le) mĕiguó }] \text { zhēn kĕxī. } \\
& \text { 3SG go-PERF America really a.pity } \\
& \text { 'It's really a pity that he went to America.' }
\end{aligned}
$$

This latter point is important for the comparison of the sentential subject structure with the structure where the verb selects a complement clause; in the latter, the presence of -le is precisely excluded for $\mathrm{V}_{1}$ (see (25a), (26a) below). Accordingly, to put these two constructions into one and the same group leads to wrong predictions concerning, e.g., the distribution of the aspectual suffix $-l e$ and must therefore be rejected.

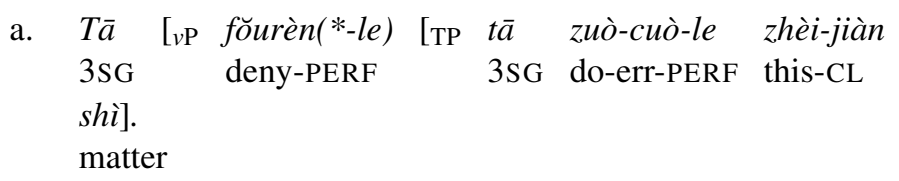



b. Tā fŏurèn(-le) [DP zhèi-ge cuòwù] 3SG deny-PERF this-CL mistake 'S/he denied this error.'

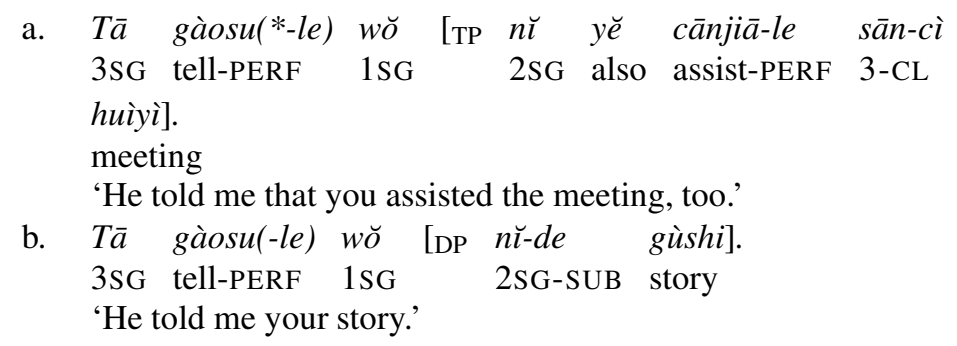

The (b) examples with a nominal complement show that the verbs themselves are perfectly compatible with -le and that the unacceptability of -le in (25a)(26a) must therefore be due to the structure. Note that the clausal complement is finite and allows for an overt subject as well as aspect markers.

Finally, the verb in the clausal complement can be negated independently of the matrix predicate, indicating that it constitutes a propositional domain of its own:

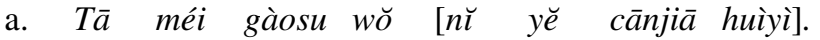 $3 \mathrm{SG}$ NEG tell $1 \mathrm{SG} 2 \mathrm{SG}$ also attend meeting 'He didn't tell me that you, too, attended the meeting.'

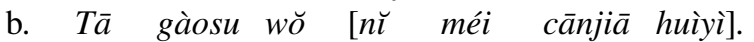 $3 \mathrm{SG}$ tell $1 \mathrm{SG} 2 \mathrm{SG} \mathrm{NEG}$ attend meeting 'He told me that you didn't attend the meeting.'

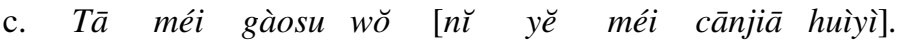 $3 \mathrm{SG}$ NEG tell $1 \mathrm{SG} 2 \mathrm{SG}$ also NEG attend meeting 'He didn't tell me that you, too, didn't attend the meeting.'

Two completely different constructions, one involving a sentential subject, the other involving a complement clause subcategorized for by the matrix verb, are subsumed under the same (second) type (of SVC). The distribution and interpretation of negation as well as the possibility of an overt subject indicate that the sentential subject and the complement clause form a propositional domain independent of the matrix predicate, with a subject different from the matrix subject. Consequently, the structure with a sentential subject and that with a clausal complement do not even satisfy the loosest of all "criteria" for "SVC-hood", i.e., uniqueness of the subject within an SVC.

As for Li and Thompson's (1981: 600) statement that "in sentences of this type [with a complement clause, cf. (25)-(26); WP] the meaning of the first verb determines the type of verb phrase or clause that functions as its direct 
object", it amounts to acknowledging the selectional restrictions imposed by a verb on its complement. To impose selectional restrictions, however, is a general property of verbs and not a particularity of verbs when part of a SVC.

Last, but not least, the discussion so far already amply illustrates the consequences of the fundamental indeterminacy of the term SVC, which allows to subsume under the same label four completely different structures: the adjunct structure (with $\mathrm{V}_{1}$ contained in a clause adjoined to the matrix $v \mathrm{P}$ ), the purpose clause structure (with $\mathrm{V}_{1}$ heading the matrix $v \mathrm{P}$ ), the sentential subject structure (with $V_{1}$ in the sentential subject), and the complement clause structure (with $\mathrm{V}_{1}$ in the matrix predicate selecting a clausal complement).

The third type of SVC postulated by Li and Thompson is the so-called pivotal construction where "a noun phrase [...] is simultaneously the subject of the second verb and the direct object of the first verb" (Li and Thompson 1981: 607). Once again this is not a special construction typical of Chinese nor of "serializing" languages. On the contrary, it instantiates the object control construction well-known from other languages, where the matrix object controls, i.e., determines the reference of, the null subject in the embedded nonfinite clause (cf. Ross 1991; Lee 1996: 315; Tang 2000): ${ }^{12}$

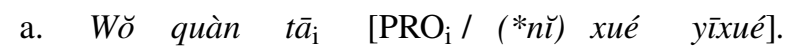

$$
\begin{aligned}
& 1 \mathrm{SG} \text { advise } 3 \mathrm{SG} \quad 2 \mathrm{SG} \text { study medicine }
\end{aligned}
$$

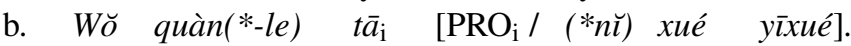 $1 \mathrm{SG}$ advise-PERF $3 \mathrm{SG} \quad 2 \mathrm{SG}$ study medicine

An overt subject being excluded, the clausal complement of an object control verb is clearly nonfinite, as in the case of the clausal complement of subject control verbs (cf. Huang 1982: 5.4; Li 1990; Tang 2000):

$$
\begin{aligned}
& \text { Wo zhunbei [PRO mingtian lai]. } \\
& \text { 1SG prepare } \\
& \text { 'I expect to come tomorrow.' (Huang 1982: 350, (87)) }
\end{aligned}
$$

Note that the nonfinite clause in the (subject and object) control structure may be negated (cf. (30)-(32), unlike the nonfinite clause in the purpose clause structure (33):

\footnotetext{
12. While there is a consensus about the nonfinite nature of the clausal complement with control verbs, among the studies cited only Tang (2000: 201) discusses the size of this complement, which is TP for him.
} 
Wŏ quàn tā bù yào $x \bar{l} \quad d \hat{u}^{13}$

1SG advise 3SG NEG want inhale drug

'I advised her not to take drugs.'

(31) Wŏ qiú tā bù yào bèipàn wŏ.

$1 \mathrm{SG}$ beg $3 \mathrm{SG}$ NEG want betray $1 \mathrm{SG}$

'I implored her not to betray me.'

Wŏ dāying Lŭsì bù bă mìmì gàosu biérén.

1SG promise Lisi NEG BA secret tell somebody

'I promised Lisi not to divulge his secret.'

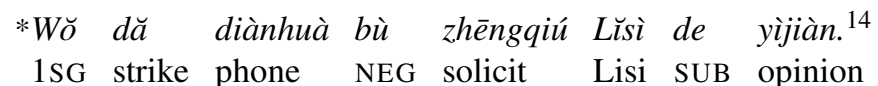
(intended meaning: 'I phoned, but not in order to solicit Lisi's opinion.')

The fourth type of SVC finally, called descriptive clause construction by $\mathrm{Li}$ and Thompson (1981: 611) and having the surface form 'S V O XP', has been analyzed by Huang (1984a, 1987) as involving a (secondary) predication (XP) on the object NP. This analysis allows him to account for the different constraints holding for the object NP as well as for the matrix predicate.

First, the object NP must be specific and indefinite; definite NPs and bare nouns are excluded (cf. (34a), (35a)):

a. Wŏ pèngdào-le yī-ge wàiguórén / *nèi-ge wàiguórén / 1SG meet-PERF 1-CL foreigner / that-CL foreigner / *wàiguórén huì shuō zhōngguóhuà.

foreigner can speak Chinese

'I met a/that foreigner/foreigners who can speak Chinese.'

13. As pointed out by Li, Y.A. (1990: 21-22) and Tang (2000), not all auxiliaries are excluded from non-finite propositions. While, e.g., yao 'want, intend' is admitted here (cf. (30), (31)), hui indicating the future is not:

(i) *Wŏ quàn / bì tā huì lái.

$1 \mathrm{SG}$ advise / force 3SG will come

(Li, Y.A. 1990: 22, (12a))

14. In order to express the meaning intended here, one must use the sentential negation bù shì 'it is not the case'(for the differences between bù and bù shì, cf. a.o. Teng 1974):

(i) Wŏ dă diànhuà bù shì zhēngqiú Ľš̀ de yìjiàn, shì qǔng 1SG strike phone NEG be solicit Lisi SUB opinion be invite

Ľ̌sì chī fàn.

Lisi eat food

'I phoned, not in order to solicit Lisi's opinion, but in order to invite Lisi for a meal.' 
b. Wŏ pèngdào-le [DP (ȳ / nèi-ge) [TP huì shuō 1SG meet-PERF 1 / that-CL can speak zhōngguóhuà] de wàiguórén].

Chinese SUB foreigner

'I met a/that foreigner/foreigners who can speak Chinese.'

a. Tā chăo-le ȳ̄-ge cài / *nèi-ge cài / *cài 1SG fry-PERF 1-CL dish / that-CL dish / dish tèbié hăochī. especially delicious 'He prepared a/that dish/dishes which is/are particularly delicious.'

b. Tā chăo-le [DP (ȳ / nèi-ge) [AP tèbié $1 \mathrm{SG}$ fry-PERF 1 / that-CL especially hăochī] de cài]. ${ }^{15}$ delicious SUB dish 'He prepared a/that particularly delicious dish/ particularly delicious dishes.'

(34b) and (35b) show that no similar constraints hold for prenominal modifiers; the relative clause huì shuō zhōngguóhuà 'who can speak Chinese' and the AP tèbié hăoch ' 'particularly delicious' are acceptable, irrespective of the nature ((in)definite), (non)referential) of the NP.

Second, the matrix predicate must be "existential" of some sort, either by its inherent lexical meaning (as in the case of, e.g., yŏu 'have', fāshēng 'happen') or by the fact that it is marked with the perfective aspect suffix -le or the experiential aspect suffix -guo; otherwise e.g., with the durative aspect marker zài or with a future-oriented auxiliary such as xiăng 'want to' in the matrix predicate, the secondary predicate is not acceptable:

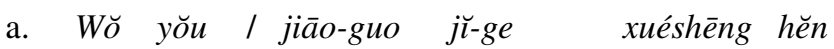
1SG have / teach-EXP several-CL student very yònggōng.

diligent

'I have/ taught several students who are very diligent.'

b. *Wŭ zài jiāo jü-ge xuéshēng hĕn yònggōng. 1SG DUR teach several-CL student very diligent ('I'm teaching several students who are very diligent.')

15. For arguments in favour of adjectives as a part of speech distinct from (stative) verbs, cf. Paul (2005a) and references therein. 


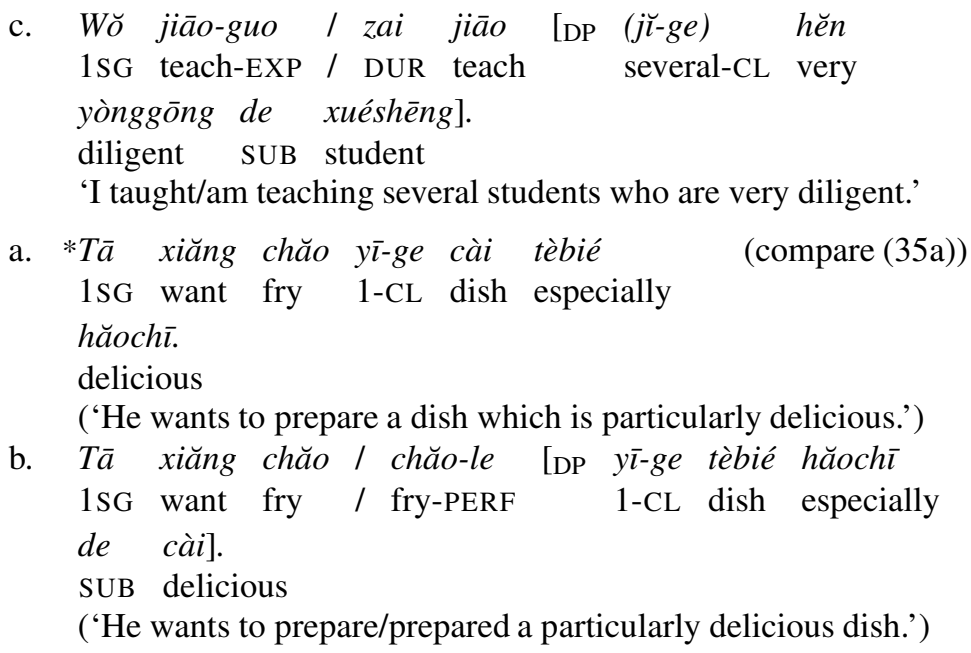

In the case of prenominal modifiers (cf. (36c), (37b)), by contrast, no such requirements on the matrix predicate are observed.

As Huang (1984a, 1987) points out, the constraints holding for both the matrix predicate and the object DP are incompatible with an analysis considering the modifier XP as part of the DP. For it would be very unusual for a nominal modifier to be acceptable only if the DP in question is indefinite/specific and to depend on the nature of the VP. Taking furthermore into account that the XP provides a non-restrictive modification, he concludes to its status as a secondary predicate (Huang 1987: 235). The "specificity effect" stated for the object DP is attributed to the general existential nature of the matrix predicate, similar to the definiteness effect observed for existential constructions in English (Safir 1982), although Huang (1987: 250) himself as well as Tsai (1994: 171-175) acknowledge problems for this explanation. Huang (1984a: 569) proposes a structure along the following lines: ${ }^{16}$

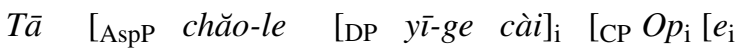

$$
\begin{aligned}
& \text { 3SG fry-PERF 1-CL dish } \\
& \text { tèbié hăochī]]]. } \\
& \text { particularly delicious } \\
& \text { 'He prepared a particularly delicious dish.' }
\end{aligned}
$$

16. Both Huang (1984a, 1987) and Tsai (1994: 169) (who adopts Huang's analysis) concentrate on the nature of the empty category within the clause predicating on the matrix object and do not indicate the exact size of the clause nor the structure above it. However, in the text Huang (1984: 232) states explicitly that "the sequence V - NP - XP is dominated by VP", i.e., the secondary predicate is embedded in $v \mathrm{P}$ or AspP, respectively. 
With respect to the nature of the empty category, analyzed as a variable bound by an abstract operator, the structure with the secondary predicate resembles the structure for the purpose clause with a covert object in addition to the covert subject:

$$
\begin{aligned}
& T \bar{a}_{\mathrm{i}} \quad z h \breve{u} \quad t \bar{a} n g_{\mathrm{j}} \quad\left[\mathrm{CP}_{\mathrm{CP}} \mathrm{Op}_{\mathrm{j}}\left[\mathrm{IIP}_{\mathrm{pro}_{\mathrm{i}}} h \bar{e} \quad \mathrm{t}_{\mathrm{j}}\right] . \quad \quad\right. \text { (=(13) above) } \\
& \text { 3SG cook soup drink } \\
& \text { 'He cooked soup to drink.' }
\end{aligned}
$$

There are, however, two major differences. The purpose clause contains a PRO controlled by the matrix subject, and furthermore, the matrix object DP here is not subject to any conditions such as the specificity effect, as witnessed by the acceptability of a bare noun as object in (39).

The preceding discussion of the structure involving a secondary predication shows that the constraints at work here are completely different from those observed for the other "types" of SVC, i.e., the adjunct structure, the purpose clause structure, the sentential subject structure, the complement clause structure, and the control structure. ${ }^{17}$ This once again questions the plausibility of subsuming all these distinct structures under the same label SVC.

To summarize my critical analysis of the seven "types" of SVC established by Li and Thompson (1981), ${ }^{18} \mathrm{I}$ have argued in detail that completely different constructions are involved here, with in each case a different set of syntactic and semantic properties. ${ }^{19}$ In this respect, $\mathrm{Li}$ and Thompson (1981) are representative of the Chinese literature which adopts an equally large coverage of the term SVC. Li, Linding (1986: Ch. 14), for example, on the one hand excludes coordinate constructions and control constructions from the phenomena subsumed under the term SVC, but on the other hand includes structures not considered as SVC by $\mathrm{Li}$ and Thompson, such as complex sentences with conditional and clausal clauses as well as sentences with preverbal adjunct PPs.

17. This approach is not only unsatisfying from a theoretical point of view, but also from a pedagogical one. For its descriptive inadequacy leads to wrong predictions concerning the distribution of aspect markers, negation etc., the correct knowledge of which is indispensable to every language learner.

18. Given that some of the four major types are further subdivided, we obtain no less than seven "types" of SVC. This quantitative inflation in itself already hints at the futility of using the same cover term SVC.

19. Examing SVCs in Cantonese, Matthews (2006) criticizes Li and Thompson (1981) for their too encompassing view of the term SVC and excludes object control structures as well as complement clause structures, because they are not monoclausal and do not have the same subject. On the other hand, he nevertheless maintains the concept of SVC as a useful one for the description of Sinitic languages and considers adjunct structures, purpose clause structures, and causative structures of the type 'I made him fall' as instances of SVC. 
Zhu, Dexi (1982: Ch. 12) likewise discards coordinate constructions and treats sentences with preverbal adjunct PPs (cf. (11) above) as SVC; in contrast to $\mathrm{Li}$, Linding (1986), however, subject and object control constructions are included among the SVC, along with other structures. Lü, Shuxiang (2000: $36 \mathrm{ff}$.) also classifies as SVC nearly as wide an array of phenomena as Li and Thompson (1981), again with the noteworthy exception of coordinate constructions. ${ }^{20}$

To indistinctly call all of these cases "SVC" amounts to no more than stating the rather trivial fact that they all contain two (or more) verbs. The term SVC, despite its claim to the status of construction, is therefore nothing else but a surface label referring to the linear sequence of constituents, and in no case gives us any indication as to the hierarchical relationship between the verbs, let alone the exact syntactic structure of the sequence at hand. Viewed from this perspective, the great majority of Chinese sentences could be considered SVCs. This is indeed what Li and Thompson (1981: 594) claim: “[...] in Mandarin there are many sentences that all have the same form, namely [...] (NP) V (NP) (NP) V (NP) [... ]". Last, but not least, note that all the constructions subsumed under the single term SVC by Li and Thompson also exist in so-called "nonserializing" languages, which makes the term SVC completely void.

\subsection{SVC in a "narrow” sense (Li and Thompson 1973)}

As discussed in detail above, in Li and Thompson's (1981) conception, the term SVC covers a very large variety of phenomena. As to be argued for in this section, even their earlier and more constrained view of what constitues an SVC (cf. Li and Thompson 1973) proves equally inadequate, because once again the term construction is employed as a pure surface label encompasssing separate constructions with different syntactic and semantic properties.

Let us first look at the quote below from Li and Thompson (1973: 99):

We claim [...] that it is 'knowledge of the world', and not linguistic knowledge which is responsible for suppressing or encouraging a particular reading for a

20. In comparison, Chao (1948: 38, 1968: 325), who was the first to introduce the concept of SVC into Chinese linguistics, under the label of verbal expressions in series, adopts a much more restrictive view:

Verbal expressions in series ( $\mathrm{V}-\mathrm{V}$ series) form an intermediate type between coordinate and subordinate constructions, but are nearer the latter than the former. [...] a V-V series is like a coordinate construction in that it can usually be reversed and remain grammatical, but differs from it in not being reversible without involving a probable change in the sentence value. (Chao 1968: 325-326).

Furthermore, for Chao (1968) the verbs in a SVC are assumed to have the same subject, a property which is not stated explicitly but becomes apparent when used as a criterion to distinguish SVCs from object control constructions (cf. Chao 1968: 327). 
serial verb sentence. [...] the choice between them in any given speech situation depends on the context and the hearer's knowledge of what the world is like. What is the optimal linguistic account of these facts? We will demonstrate in the following that there is ample evidence in favor of a structural distinction between one serial verb representation expressing purpose and another expressing any of the conjunction meanings [...] we claim, then, that sentences with consecutive, simultaneous, and alternating action readings are all structurally conjunctions, and that such sentences do not convey any structural or semantic information concerning the relationship in time between the two events in the predicate. Whether the actions are taken to be consecutive, simultaneous, or alternating depends completely on inferences which the hearer makes.

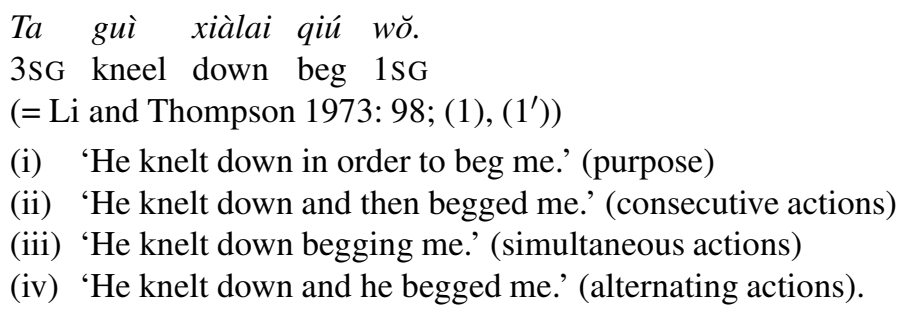

$\mathrm{Li}$ and Thompson (1973) is clearly superior to their own subsequent analyses in acknowledging two different structures, a coordinated one for the interpretation in terms of consecutive, alternative or alternating actions, on the one hand, and a subordinate one for the purpose clause interpretation, on the other hand. Nevertheless, their point of view remains problematic. ${ }^{21}$

First, they do not make the in fact logically necessary step to the conclusion that the so-called SVC cannot be a unique construction if it can systematically be assigned two completely different structures with separate properties. Instead, they state a systematic ambiguity for the SVC in Chinese ( $\mathrm{Li}$ and Thompson 1973: 102).

Second, the multiple ambiguity claimed for a surface string such as (40) by $\mathrm{Li}$ and Thompson (which in fact would be a case of structural ambiguity) does not actually exist to that extent. More precisely, sentences with a simple juxtaposition of VPs and without overt marking indicating the relation between these two VPs do not lead to an interpretation in terms of simultaneous, alternating or consecutive actions, i.e., they cannot be analyzed as coordinate structures (cf. Chen 1993: 50; Chan 1974). As discussed in Section 2.1. above

21. Note that Li and Thompson (1973) went more or less unnoticed and that it was Li and Thompson $(1974,1981)$ which had the biggest impact on the field. As later in their grammar (Li and Thompson 1981), Li and Thompson (1974) only mention the availability of different interpretations for a sentence such as (40) and do not link the observed difference in interpretation with a difference in structure, as they do in Li and Thompson (1973). 
(cf. (16), (17)), a pause between the two VPs or explicit marking by, e.g., adverbs (such as yimian ... yimian 'at the same time') is indispensable for an analysis in terms of a coordinate structure. For the juxtaposition of VPs in the absence of any marking, this analysis is precisely not avalaible, and even less so a default analysis.

Instead, sentences with a simple juxtaposition of VPs such as (40) are either analyzed as a purpose clause structure (corresponding to (40i)) or as an adjunct structure (giving rise to the interpretation dubbed "circumstance" by $\mathrm{Li}$ and Thompson 1981, which is not discussed by Li and Thompson 1973):22

$$
\begin{aligned}
& T \bar{a}_{\mathrm{i}} \quad\left[{ } _ { \nu \mathrm { P } } \text { guì xiàlai } \left[{ }_{\mathrm{CP}} \mathrm{PRO}_{\mathrm{i}}\right.\right. \text { qiú wŏ]]. } \\
& \text { 3SG kneel down beg } 1 \mathrm{SG}
\end{aligned}
$$

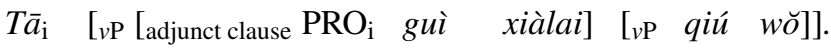

$$
\begin{aligned}
& \text { 3SG kneel down beg 1SG }
\end{aligned}
$$

'He begged me kneeling down/on his knees.'

The 'A-bù-A' question (cf. Huang 1982) provided as a test by Li and Thompson (1973) to distinguish the purpose clause structure from a coordinate structure can equally be used to illustrate the syntactic differences between the purpose clause structure (41) and the adjunct structure (42) (in addition to the aspect marking test provided in Section 2.1. above). As pointed out by $\mathrm{Li}$ and Thompson (1973: 101), sentence (43) where the positive and the negative form of the verb are juxtaposed to indicate the question status can only be interpreted as a purpose clause:

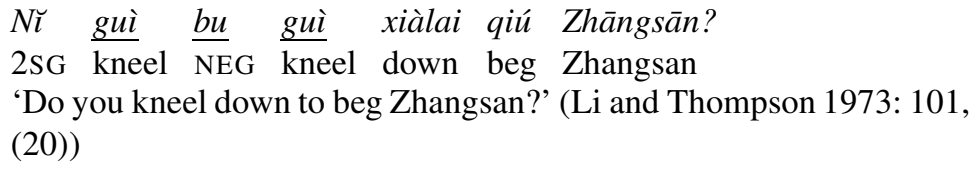

While Li and Thompson (1973) associate the 'A-bù-A' question formation with main verb status, Tang (2000) demonstrates that the crucial factor is in fact finiteness. Since the purpose clause itself has been shown to be nonfinite (cf. Section 2.1 above), main verb status and finiteness coincide here. This can also be illustrated for my example of a purpose clause structure given above, where the 'A-bù-A' question formation again must apply to the matrix predicate $\left(\mathrm{V}_{1}\right)$ :

22. The three interpretations (40ii-iv), including the one of simultaneous actions (iii), being explicitly linked to a coordinate structure, $\mathrm{Li}$ and Thompson (1973) do not take into account the adjunct structure nor the meaning associated to it: 'He begged me kneeling down/on his knees.' 
(44) as well can only be parsed as a purpose clause structure with kai hui 'hold meeting' as the matrix predicate.

When it is the second verb that is in the 'A-bù-A' form (a case not discusssed by Li and Thompson 1973), the resulting sequence must be parsed as a complex sentence:

$$
\begin{aligned}
& \text { [TорР [тр } \text { Tămen }_{\mathrm{i}} \quad k \bar{a} i \text { huì] [тр } \text { pro }_{\mathrm{i}} \text { tăolùn bù tăolùn } \\
& \text { 3PL hold meeting discuss NEG discuss } \\
& \text { nèi-ge wèntí]]? } \\
& \text { that-CL problem } \\
& \text { 'When they hold a meeting, will they discuss that problem?' }
\end{aligned}
$$

While this is partly as expected insofar as the VP in the A-bù-A form must again be analyzed as the matrix predicate, the constituent containing the first VP does not constitue an adjunct clause with a covert subject (cf. (42)), but rather represents a temporal clause (with an overt subject) occuping the specifier of Topic Phrase (cf. Gasde and Paul 1996). ${ }^{23}$ Importantly, even though this parsing as a complex sentence is somewhat different from what we expected at first sight, it does not involve a coordinate structure, once again strengthening the observation made above that such an analysis requires overt marking.

We thus obtain the following picture. The default analysis of a surface string ' $\mathrm{VP}_{1} \mathrm{VP}_{2}$ ' without any markers is either an analysis where the first VP is an adjunct of the second (main) VP, or an analysis where the first VP is the main VP and the second VP represents a purpose clause whose covert subject is controlled by the matrix subject. An analysis as a coordinate structure is, however, excluded. Consequently, even Li and Thompson's (1973) "narrow" conception of the SVC as denoting two or more separate events giving rise to four different "interpretations" (purpose; consecutive, alternating, or simultaneous events) remains inadequate. For it wrongly claims the coordinate structure analysis (underlying the interpretation as consecutive, alternating

23. The analysis provided in (45) with tämen 'they' as subject of the first clause, and not the second, is motivated by sentences such as (i) where the main clause contains a subject different from the clause in Spec, TopP:

(i)

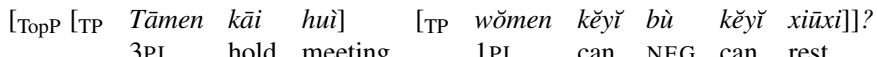

$$
\begin{aligned}
& \text { 'May we rest when they hold a meeting?' } \\
& 1 \mathrm{PL} \text { can NEG can rest }
\end{aligned}
$$


or simultaneous events) to be among the parsing possibilities. Furthermore, it makes wrong predictions for the interpretation of so-called SVCs; an adjunct structure such as (42) where the first VP is in an adjunct clause modifying the second VP is understood as a single event, and not as two separate events.

\subsection{The indeterminacy of the term SVC in formally oriented studies}

The failure to correctly apply the basic notion of construction (as referring to a precise structure with a fixed set of syntactic and semantic properties) demonstrated for Li and Thompson's $(1973,1981)$ conception of SVC, is in fact ubiquitous in works invoking SVC in Chinese linguistics, also in formally oriented studies. The small sample below illustrates that the inherent indeterminacy of the term SVC leads to a surprising heterogeneity of analyses associated with SVC. It also shows that SVC are referred to in recent and current work as though a precise definition existed and the exact coverage of this term was agreed upon, contrary to fact.

Li, Y.A. (1990: 106-110) analyzes the double objet construction 'V DO gě

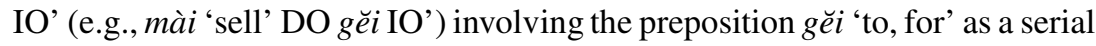
verb construction where '[V DO] [gĕi IO]' represents a sequence of two VPs whose structural relationship is not further specified, besides stating a "dependence" of $\mathrm{VP}_{2}$ on $\mathrm{VP}_{1}{ }^{24}$ This dependence not being marked overtly, the Revised Principle of Temporal Sequence comes into play requiring that the order of the syntactic units mirrors the temporal order of the corresponding events in the conceptual world (p. 108).

Li, Y. (1991: 111-113) - like Li and Thompson (1981) - classifies both the adjunct structure and the purpose clause structure as SVC, notwithstanding the fact observed by himself that in the former, the second verb is the main verb, while in the latter, it is the first verb. ${ }^{25}$

24. The VP status of ' $g \breve{e} i$ IO' in 'V DO gĕ $i$ IO' is explicitly addressed and rejected in Zhang (1990). For a recent analysis of the double object construction in Mandarin Chinese, cf. Georgala, Paul and Whitman (2007).

25. "The perfective aspect marker le must be attached to the second verb qie to maintain the instrumental reading of this sentence [= (i); WP]." (Li 1991: 112)

"What distinguishes (13a) [= (ii); WP] from (11) [= (i); WP] is that in the former, the first verb denotes the central event and given the structure of VP [...] which also allows postverbal non-heads, this verb becomes the head of the VP predicate." (Li 1991: 113).

(i) Tā ná dāo qiè-le ròu.

3SG take knife cut-PERF meat

(= Li’s 1991: 111, (11))

'He cut the meat with a knife.'

(ii) Tā ná-le dāo qiè ròu.

3SG take-PERF knife cut meat

'He took the knife to cut meat.'

(= Li’s 1991: 112, (13)) 
Tsai (1995: 292-293) analyzes SVCs in terms of two conjoined CPs linked by a topic chain, to be interpreted as two consecutive events:

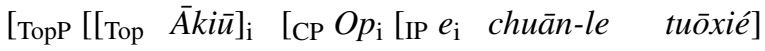

$$
\begin{aligned}
& \text { Akiu wear-PERF slipper } \\
& \text { [CP } \left.O p_{\mathrm{i}}\left[\mathrm{IP} e_{\mathrm{i}} \quad s h a ̀ n g(-l e) \quad k e ̀\right]\right] \\
& \text { attend-PERF class }
\end{aligned}
$$

'Akiu wore slippers, and then went to school.' (Tsai 1995: 293, (32))

Soh (1998: 157-161) applies a version of Collins' (1997) object sharing structure for SVCs (cf. Section 3 below) to the adjunct structure in $(47 \mathrm{a}, \mathrm{c})$, with $d \bar{a} o$ 'knife', the object of the verb ná 'take, hold' in the adjunct clause, as the alleged shared object of the two VPs (see (47b)). While it is not excluded that an instrument DP can be construed as a shared argument (e.g., in Ewe, cf. Collins 1997, Section 3.2), this is not the case in Mandarin Chinese where the clause containing ná dāo 'take knife' is clearly in an adjoined position (cf. Section 2.1 above)

$$
\begin{aligned}
& \text { a. Tā ná dāo qiè-le ròu. } \\
& \text { 3SG hold knife cut-PERF meat } \\
& \text { 'He cut the meat with a knife.' } \\
& \text { (= Soh's translation, Soh 1998: 158, (4a)) }
\end{aligned}
$$

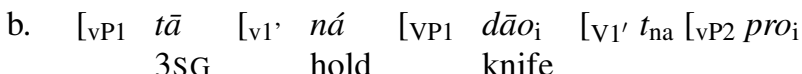

$$
\begin{aligned}
& \text { [v2' qiè-le [VP2 } \left.\left.\left.\left.\left.\left.t_{\text {qie }} \text { ròu }\right]\right]\right]\right]\right]\right] \\
& \text { cut-PERF meat } \\
& \text { (Soh 1998: 159, (6)) } \\
& \text { c. } T \bar{a}_{\mathrm{i}} \quad\left[{ }_{\nu \mathrm{P}}\left[\text { adjunct clause } P R O_{\mathrm{i}} \text { ná } d \bar{a} o\right] \quad\left[\begin{array}{lll}
{ }_{\mathrm{v}} & q i \grave{e}-l e & \text { ròu}]
\end{array}\right]\right. \\
& \text { 3SG hold knife cut-PERF meat }
\end{aligned}
$$

Also note that Soh (1998: 161) posits the possibility of object scrambling to a non-specified functional projection within the lower $v$ P, i.e., $v_{2} \mathrm{P}$. Such a proposal does not only make wrong predictions for Chinese (where TP-internal object fronting is to a position above negation, hence above $v \mathrm{P}$; cf. a.o. Ernst and Wang 1995; Paul 2002a, 2005b), but it is also a rather unusal postulate for SVC.

Finally, for Lin (2001: 222-227) a SVC involves a structure where $\mathrm{V}_{1}$ takes $\mathrm{V}_{2} \mathrm{P}$ as its complement, but without there being any object sharing. Accordingly, a sentence such as (48a) has the structure in (48b) where yòng 'use' raises to the subject selecting light verb DO: 


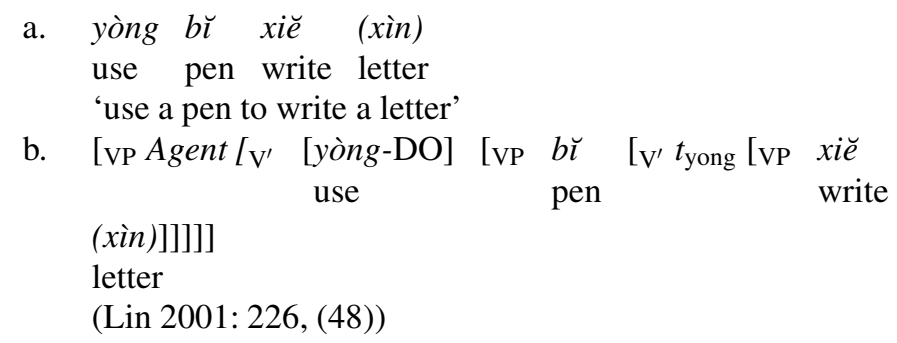

As illustrated in this short overview, more or less any structure can be associated with the term SVC; there exists no general awareness that the term SVC lacks a coherent definition and should hence be used with caution or perhaps not be used at all. That this too permissive view of SVC nevertheless persists in Chinese linguistics is mainly due to the fact that SVC is a conveniently loose label for all the constructions whose precise analysis still eludes us.

\subsection{Intermediate conclusion}

Given that SVC in Chinese linguistics serves as a cover term for distinct constructions with different properties and does not refer to a unique structure with a predictable set of properties, to "know" that a given sequence is an SVC amounts to not knowing anything, neither its structure nor its syntactic and semantic characteristics. Though several linguists have come to a similar conclusion (cf. a.o. Chen 1993; Wippermann 1993), they have, however, not taken the logically necessary step: to abandon the term SVC in Chinese linguistics altogether. That is exactly what I want to propose here, the more so as the phenomena labelled SVC so far in Chinese have turned out to be structures present in so-called "non-serializing" languages as well.

To obtain a clear picture is not only important for the description and analysis of Chinese itself, but also for typological studies aiming to compare languages with SVC. For example, parallels have been drawn between the so-called SVC in Mandarin Chinese and SVC in Niger-Congo languages (cf. Lefebvre 1991; Lord 1973; Li and Thompson 1974) without there being any effort to first check the coverage of the term in the two language families. As to be discussed in the following section, this lack of awareness of the numerous problems related to the label SVC has led scholars to equate phenomena which in fact are incommensurate. 


\section{The term SVC in African linguistics (Niger-Congo languages)}

While there exists a certain consensus that a SVC in Niger-Congo languages is not a coordinate structure, denotes a single (composite) event, presents one clausal domain (as evidenced by a unique tense/aspect value) and displays argument sharing (i.e., a common subject and/or object) (cf. Baker 1989; Déchaine 1993; Stewart 1996; Collins 1997, 2002), the exact coverage of the term SVC as well as its defining properties are nevertheless still under debate. A closer look reveals that here, as well, scholars further subdivide SVC into different "types" and thus allow for different constructions to be subsumed under one and the same label. This is the more surprising as in the discussion of SVC in Niger-Congo languages the authors are rather explicit about the structures proposed and do not - as in Chinese linguistics - mainly rely on different interpretations in order to motivate different types of SVC.

One of the main types of SVC acknowledged for Niger-Congo languages is the object sharing type, described a.o. by Collins $(1997,2002)$ for the Kwa language Ewe. This analysis is presented in some detail here, not only to illustrate the tests allowing to distinguish the SVC from other superficially similar constructions, but also because it will be referred to in the discussion of the Mandarin Chinese bă-construction in Section 4.1 below.

Taking up previous works by Déchaine (1986), Foley and Olson (1985) and Baker (1989), Collins (1997) chooses object sharing as the crucial criterion for the SVC, more precisely, sharing of the internal argument. It is sharing of the internal argument rather than object sharing because this allows to include cases such as (49) where fufu is both the object of $d a$ 'cook' and $d u$ 'eat' as well as cases such as (50) where 'child' is the object of chase and the unique, and for that matter, internal argument of $d z o$ 'leave':

Wo da fufu du.

3PL cook fufu eat

'They cooked fufu and ate it.' (Collins 1997: 461; (3))

(N.B. Collins' translation is not meant to imply a coordinate structure for (49).)

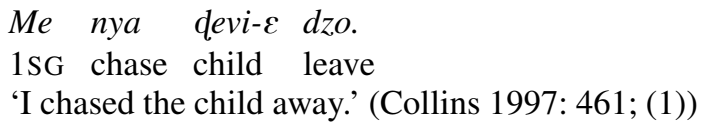

The structure Collins (1997: 491) proposes is given in (51) where $\mathrm{V}_{1}$ selects $\mathrm{V}_{2} \mathrm{P}$ as its complement and where the (covert) internal argument of $\mathrm{V}_{2}$ is coreferent with that of $\mathrm{V}_{1}$. More precisely, the object of the first verb controls the empty category in the specifier position of $\mathrm{V}_{2} \mathrm{P}$ (analyzed as pro by Collins 
1997: 478). $\mathrm{V}_{2} \mathrm{P}$ is analyzed as a kind of secondary predication, a proposal similar to that by Larson (1991).

(51)

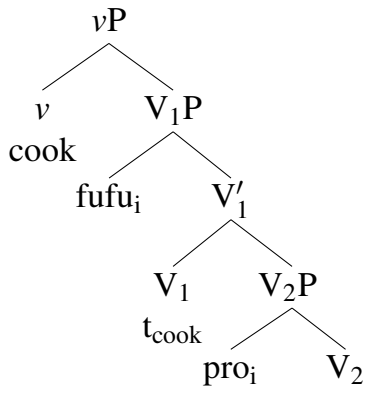

As indicated in (51), $\mathrm{V}_{1}$ raises to small $v$.

The control structure in (51) correctly predicts the unacceptability of an overt pronoun following the second verb:

$$
\begin{aligned}
& \text { Wo-a da fufu du }-(* i) . \\
& \text { they-Fut cook fufu eat it } \\
& \text { 'They will cook fufu and eat it.' (= Collins 1997: 480, (60b)) }
\end{aligned}
$$

Furthermore, Collins provides evidence for the distinction between the SVC in (53) and coordinate structures in Ewe: whereas in the SVC the future is marked only on the first verb (cf. 53b)), in a coordinate structure it must appear in front of each verb (cf. (54)):

\section{a. Me fo kadegbe gba.}

I hit lamp break

'I hit the lamp and broke it.' (= Collins 1997: 463, (7))

b. Me a fo kadggbe gba.

I FUTURE hit lamp break

'I will hit the lamp and break it. ${ }^{26}$ (= Collins 1997: 463, (9))

$$
\begin{aligned}
& \text { Me } \quad \underline{a} \text { fo kadggbe } *(\underline{a}) \text { gba } \quad \text { (ycme) tsimini. } \\
& \text { I FUT hit lamp FUT break its glass } \\
& \text { 'I will hit the lamp and break its glass.' (= Collins 1997: 463, (10)) }
\end{aligned}
$$

(54) does not involve argument sharing. Hence, it is not a SVC, but a case of parataxis or covert coordination (cf. Baker 1989) and needs future marking on both verbs. ${ }^{27}$

26. Collins (1997) does not give any translation for (53b) nor for (54).

27. The presence of the future markers shows that what is coordinated here are IPs or I-bars rather than VPs or V-bars. Collins points out that Ewe does not allow covert coordination of VPs 
Collins (2002) extends this analysis to verbal compounds in $\neq$ Hoan (cf. (55)) for which he posits an object sharing SVC as underlying structure:

$$
\begin{aligned}
& \text { a. } \begin{array}{l}
M a-\quad q \| h u \text { I'o djo } \\
\text { 1SG PROG pour put.in water PART pot in }
\end{array} \\
& \text { 'I am pouring water into the pot.' (Collins 2002: 1, (1)) }
\end{aligned}
$$

b. $\quad\left[{ }_{v \mathrm{P}} \mathrm{DP}\left[v_{v^{\prime}}\left[v\right.\right.\right.$ pour $[v$ put.in $v]\left[\mathrm{vP1} \mathrm{DP}_{\mathrm{i}}\left[\mathrm{v}_{1} \mathrm{t}_{\mathrm{pour}}\left[\mathrm{vP2} \mathrm{PRO}_{\mathrm{i}}\right.\right.\right.$ $\left[\mathrm{V} 2^{\prime} \mathrm{t}_{\text {put.in }}[\mathrm{PP}\right.$ pot in]]]]]

(55a) is derived by adjoining both $\mathrm{V}_{1}$ and $\mathrm{V}_{2}$ (in that order) to the light verb $v$. Note that Collins (p. 10) here assumes "tucking in" à la Richards (1997). ${ }^{28}$

The difference between a SVC language such as Ewe where only $\mathrm{V}_{1}$ moves to $v$ (cf. (51) above) and $\mathrm{V}_{2}$ remains in situ, on the one hand, and a SVC language such as $\neq$ Hoan with verbal compounds resulting from the movement of both verbs, on the other, is explained by the general requirement for verbs in $\neq$ Hoan to adjoin to $v$. (p. 9), a requirement absent from the syntax of Ewe.

The analysis of $\neq$ Hoan verbal compounds as underlying SVCs makes it necessary for Collins (2002: 9) to revise the serialization parameter in (56) and to replace it by (57). While English, French and Swahili have a negative setting for (57), Ewe, Yoruba, $\neq$ Hoan, and Chinese are said to have a positive setting.

$$
\begin{aligned}
& \text { Infl (tense) can license multiple Vs. } \\
& \text { (Collins 1997) }
\end{aligned}
$$

The light verb $v$ can license multiple Vs.

(Collins 2002: 9, (24))

If we now turn to the list of structures labelled SVC in Chinese (cf. Section 2.1 above), we state that the structures proposed by Collins in (51) and (55b) for an object sharing SVC do not figure among the SVC types established for modern Mandarin.

Baker and Stewart (2002) argue for the need to refine the classification of SVCs. They distinguish between resultative, purposive and consequential SVCs. (Examples given below are from the Kwa language Èdó.)

or V-bars, because otherwise a covert coordination with only one future marker should be possible.

28. Collins (2002: 13, (38)) lists the following generalizations needed to derive the correct word order for verbal compounds in $\neq$ Hoan:

a. Verbs always adjoin to the left.

b. A verb cannot adjoin to another verb. Rather, a verb must adjoin to a functional head (such as $v$, T, or C.).

c. The trace of a verb does not block movement.

d. A verb always adjoins as close as possible to $v$ (Local Move). 


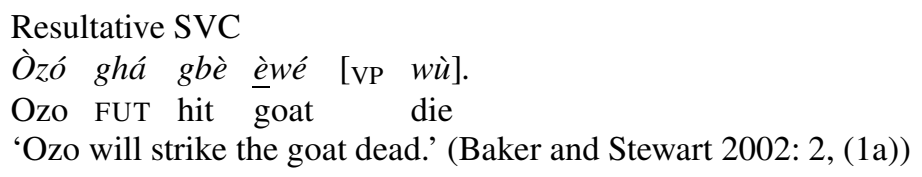

A resultative SVC describes a single event where $V_{2}$ (an unaccusative verb) denotes the result of the action expressed by $\mathrm{V}_{1} . \mathrm{VP}_{2}$, the complement of $\mathrm{V}_{1}$, does not contain any overt or covert argument (i.e., the internal argument sharing leading to the interpretation of the matrix object as theme is not encoded syntactically via an empty category.)

$$
\begin{aligned}
& \text { Purposive SVC }
\end{aligned}
$$

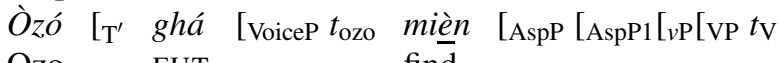

$$
\begin{aligned}
& \text { Ozo FUT find } \\
& \left.\left[\mathrm{NP} \text { ìyán]]]] [AspP2 } O p \text { lé }{ }_{\mathrm{\nu P}[\mathrm{vP} 2} t_{\mathrm{V}}\right]\right] .{ }^{29} \\
& \text { yam cook }
\end{aligned}
$$

'Ozo will find yams to cook (and do so).' (Baker and Stewart (2002: $3,(3 a))$

In the purposive SVC, the transitive $\mathrm{V}_{2}$ is embedded in an AspP and object sharing is mediated via the presence of an operator in $\mathrm{Spec}, \mathrm{AspP}_{2}$. AspP $\mathrm{A}_{2}$ itself is adjoined to $\mathrm{AspP}_{1}$. Baker and Stewart note that while the action expressed by $\mathrm{V}_{2}$ is understood as asserted in the Èdó example above, this is not necessarily the case in purposive SVCs in other languages such as Nupe.

$$
\begin{aligned}
& \text { Consequential SVC }
\end{aligned}
$$

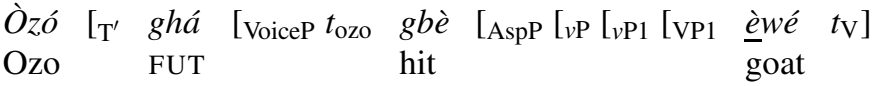

$$
\begin{aligned}
& \text { [vP2 khièn [vP2 pro tv]]. } \\
& \text { sell }
\end{aligned}
$$

'Ozo will kill the goat and sell it.' (Baker and Stewart 2002: 2, (1a))

The consequential SVC finally describes a composite event with two distinct subevents. Internal argument sharing is mediated by a pro present in the VP headed by (the transitive) $\mathrm{V}_{2}$ and dominated by $v \mathrm{P}_{2}$. This $v \mathrm{P}_{2}$ in turn is adjoined to $v \mathrm{P}_{1}$.

If we now want to check whether these structures can be found among those listed as SVC in Chinese, we must once again admit defeat. Though on the surface and from an interpretative point of view, Baker and Stewart's purposive SVC seems to correspond to a Chinese purpose clause such as (61) (with a

29. Concerning the movement of V1 and V2 in Examples (59) and (60), only the original position and the landing site are indicated, but not the intermediate steps. 
covert object in addition to the covert subject), the associated structures are completely different:

$$
\begin{array}{llllll}
T \bar{a}_{\mathrm{i}} & z h \breve{u} & t \bar{a} n g_{\mathrm{j}} & {\left[\mathrm{CP} O p_{\mathrm{j}}\right.} & {\left[\begin{array}{llll}
\text { IIP } & \text { pro } & h \bar{e} & t_{\mathrm{j}}
\end{array}\right] .} \\
\text { 3SG cook } & \text { soup } & \text { drink } & & \\
\text { 'He cooked soup to drink.' } &
\end{array}
$$

In the Chinese purpose clause structure (61) the $\mathrm{CP}$ into which $\mathrm{V}_{2}$ is embedded is structurally a complement of $\mathrm{V}_{1}$, and not adjoined to a projection containing $\mathrm{V}_{1}$. Given the fact that in Chinese constituents appearing to the right of the main verb on the surface must occupy a position lower than the verb (cf. Huang 1982 and subsequent work), the adjunction scenario proposed by Baker and Stewart (2002) for purposive and consequential SVCs is completely excluded for Chinese.

Unlike Collins (1997, 2002) and Baker and Stewart (2002), Law and Veenstra (1992) do not take as a starting point a Niger-Congo language, but base themselves on Jamaican Creole. They propose a distinction between theme serials and instrumental serials. A theme serial (cf. (62a)) is roughly equivalent to the internal argument sharing SVC à la Collins, modulo the difference that object sharing is mediated by an operator (adjoined to the second predicate).

$$
\begin{aligned}
& \text { a. }\left[\mathrm{vp}\left[\mathrm{V}^{\prime}\left[\mathrm{V}^{\prime}, \mathrm{V}_{1} \mathrm{NP}_{\mathrm{i}}\right]\left[\mathrm{vp} \text { Op }\left[\mathrm{vp} \text { PRO }\left[\mathrm{V}^{\prime} \mathrm{V}_{2} \mathrm{t}_{\mathrm{i}}\right]\right]\right]\right]\right] \\
& \text { (Law and Veenstra 1992: 186; (3)) } \\
& \text { b. Im tek stuon fing ina di waata. } \\
& \text { he take stone throw in-LOC the water } \\
& \text { 'He threw the stone into the water.' (Law and Veenstra 1992: 191; } \\
& \text { (13a)) }
\end{aligned}
$$

An instrumental serial, by contrast, lacks an empty category ( $w h$ trace) following $\mathrm{V}_{2}$, hence also the empty operator. The structure proposed for an instrumental serial is as follows:

$$
\begin{aligned}
& \text { a. }\left[\mathrm{vp}\left[\mathrm{V}^{\prime}\left[\mathrm{v}, \mathrm{V}_{1} \mathrm{NP}\right]\left[\mathrm{vP} \text { PRO }\left[\mathrm{V}^{\prime} \mathrm{V}_{2}\right]\right]\right]\right] \text { (Law and Veenstra 1992: } \\
& 187 ;(4)) \\
& \text { b. Im tek naif alter di hog. } \\
& \text { he take knife alter the hog } \\
& \text { 'He castrated the hog with a knife.' }
\end{aligned}
$$

As pointed out by Law and Veenstra (1992), in both cases, the unique event interpretation typical of SVC is obtained by limiting the size of the projection containing $\mathrm{V}_{2}$ to VP (rather than IP or CP).

If we now compare the Jamaican Creole examples with Chinese, sentence (63b) looks very much like the Chinese examples analyzed as adjunct clause structures (cf. (64) below). Similarly, the theme serial example can be easily 
transposed into the Chinese $b \breve{a}$ construction (cf. (65)), although again the associated structure is completely different (see Section 4 below for a detailed discussion). Although I do not have any knowledge about the syntax of Jamaican Creole, the structure proposed for its so-called instrument serial nevertheless strikes me as rather surprising, the more so as Law and Veenstra (1992: 192) themselves observe the optionality of tek naif 'take knife' in (63b), a property to be expected from an adjunct. Note in this context that Law and Veenstra (1992: 187) admit that they "are not in a position to fully defend this structure". Furthermore, they explicitly acknowledge the lack of an a priori definition of SVC and declare to "put the definition of SVCs aside and [to] use the term for convenience to refer to the surface sequence of the form 'NP V NP V' [...]." (p. 191).

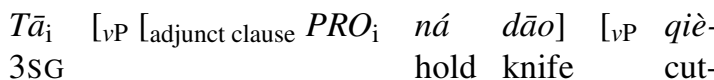

$$
\begin{aligned}
& \text { ròu]]. } \\
& \text { meat } \\
& \text { 'He cut the meat taking a knife.' } \\
& \text { Tā bă shítou rēng zài shŭ li. } \\
& \text { 3SG BA stone throw be.at water inside }
\end{aligned}
$$

This brief discussion once again demonstrates the vagueness of the term SVC and the possibility of associating different structures with it. We thus obtain the situation illustrated above where structures from Chinese and Jamaican Creole are not analyzed in the same way, although they might turn out to be identical (although not instantiating SVCs).

Last, but not least, Déchaine (1993: 800) in her overwiew article proposes a "bivalent" VP structure for SVC where one VP is adjoined to another, an approach which - as we have seen above - is equally adopted by Baker and Stewart (2002). Whether such a bivalent VP is headed by $V_{1}$ or $V_{2}$ may differ from one language to the other: while in Haitian SVC, $\mathrm{V}_{1}$ is the head, it is $\mathrm{V}_{2}$ in İgbo. However, headedness may also vary within the same language as, e.g., in the case of Yorùbá. Examining in detail the two Kwa languages İgbo and Yorùbá as well as Haitian (with a Kwa substrate) Déchaine furthermore emphasizes the differences observed in the degree to which so-called "serializing" languages make use of SVC and concludes to the unlikeliness that SVCs constitute a unitary phenomenon licensed by a single parameter.

Evidently, it is impossible here to do justice to the abundant literature on SVC in Niger-Congo languages and elsewhere and to the richness of the detailed language descriptions used as evidence for a certain conception of SVC. However, even a limited overview as the one given here should suffice to show 
that we face a situation similar to the one encountered in Chinese linguistics: when confronted with the term SVC, we do not know what structure is referred to among the different conceptions of SVC prevalent in the studies on NigerCongo languages (modulo the minimal consensus on SVC stated above), and this despite the fact that the authors are rather explicit about the syntactic structure they postulate for (each type of) SVC.

This problem linked to the indeterminacy of the term SVC increases exponentially in crosslinguistic comparison when, e.g., SVC in Chinese are to be compared with the SVC in Niger-Congo languages. In such a case, there is no way of knowing to what extent the phenomena covered by the term SVC in each language overlap, nor whether they overlap at all. Coordinate structures are a good example here: while there is a consensus that they do not count as SVC in Niger-Congo languages, they are included under SVC in Chinese. This demonstrates that the terms SVC as they are used in Chinese and African linguistics, respectively, are not commensurate. Things get even worse in typological studies where so-called "serializing" languages are confronted with so-called "non-serializing" ones and where the crosslinguistic comparison relies on the illusory assumption that in each case we deal with a well-defined homogeneous group.

\section{The importance of SVCs in diachronic and typological studies}

Unfortunately, the conceptual difference between SVCs "à la chinoise" and SVCs "à l'africaine" and the heterogeneity of the phenomena subsumed under each type is hardly paid any attention in the literature. On the contrary, in grammaticalization studies reference is often made from SVCs in Chinese to those in Niger-Congo languages and vice versa, as though one and the same phenomenon was involved (cf. Lord 1973; Lefebvre 1991). ${ }^{30}$ Furthermore, important theoretical conclusions in terms of a typologically relevant "serialization parameter" (cf. a.o. Larson 1991; Collins 1997, 2002; Den Dikken and Sybesma 1998; Stewart 2001), distinguishing so-called "serializing" from socalled "non-serializing" languages have been drawn on the basis of incommensurable phenomena. (But cf. Déchaine (1993) and Law and Veenstra (1992) who question the feasibility of a serialization parameter.) Taking the $b \breve{a}$ construction in modern Mandarin as example, this section discusses the farreach-

30. While it is true that in both language language families prepositions evolved from verbs, thus contrasting with e.g., Indo-European languages where prepositions are derived from locative case-form nouns, SVCs in Chinese have been shown to cover quite a different spectrum of phenomena from SVC in Niger-Congo languages. Thus, when Lord (1973: 292) states that "Mandarin Chinese has serial verb constructions analogous to those in Kwa", there is no way of knowing what structure she is referring to. 
ing consequences for both diachronic and typological studies arising from the indeterminacy of the term SVC and shows them to go well beyond a simple (mis)labelling issue.

\subsection{The role of SVCs in diachronic studies}

SVCs play a crucial role in diachronic syntax, because they are claimed to be the source structure par excellence for numerous grammaticalization phenomena in Chinese (cf. a.o. Zhu, Minche 1957; Wang, Li 1958; Mei 1981; Li and Thompson 1974b; Peyraube 1996; Simpson and Wu 2002; Xing 2003). One of the most extensively discussed cases is the origin of the bă construction in Modern Mandarin:

a. Tā bŭ shū rēng-le.

3SG BA book throw:away-PERF

'He threw the book(s) away.'

b. Tā rēng-le shū le.

3SG throw:away-PERF book PART

'He threw a book/books away.'

a. Tāmen bă Zhāngsān / lăohu găn-zŏu-le.

3PL BA Zhangsan / tiger expel-leave-PERF

'They chased Zhangsan/the tiger away.'

b. Tāmen găn-zŏu-le Zhāngsān / lăohu y̆hòu tèbié

3PL expel-leave-PERF Zhangsan / tiger after very gāoxìng.

happy

'After they had chased Zhangsan/a tiger away, they were very happy.'

While the postverbal position is the default position for the object DP (cf. (66b), (67b)), in the $b \breve{a}$-construction (cf. (66a), 67a), the object DP appears to the left of the verb and is preceded by $b \breve{a} .^{31}$

31. It goes beyond the scope of this article to discuss the reaons for this optionality. Suffice it to point out that the constraints holding in the $b a \breve{a}$-construction lead to the interpretation of bare nouns as definite. Cf. $\mathrm{Li}$ (2006) and references therein for an extensive overview of the relevant data and the range of analyses proposed for the $b \breve{a}$-construction.

As far as I can see, the possible co-existence of the $b \breve{a}$ construction with a corresponding structure where the object ocupies the postverbal position and the acceptability of simple verbs in the $b a \breve{~ c o n s t r u c t i o n ~(c f . ~(66 a)) ~ m a k e ~ i t ~ i m p o s s i b l e ~ t o ~ a p p l y ~ C o l l i n s ' ~(2002) ~ a n a l y s i s ~}$ of $\ddagger$ Hoan verbal compounds here, contrary to a reviewer's suggestion. For this would require Chinese to be a language where at the same time all verbs have to undergo movement to $v$ (deriving (67b)) and where only V1, or rather bă, moves to $v$ (deriving (66b)). Also note that 
Traditionally, $b \breve{a}$ is assigned prepositional status and said to have originated from a 'take' verb such as $b \breve{a}$ 'seize, hold' or jiāng 'seize, hold' occurring in an SVC, thus representing one of the many cases of V-to-P reanalysis in Chinese: ${ }^{32}$

$\begin{array}{lllll}\text { Sūnzi jiāng } & y \bar{l}-y \bar{a} & s \bar{l} & \text { yòng. } \\ \text { Sunzi take } & 1 \text {-duck } & \text { privately } & \text { use }\end{array}$

'Sunzi grabbed a duck and used it for himself.'

(Zhang Zhuo, Chao ye qian zai; 8th c., from Zhu, Minche 1957: 18)

Qìng jiāng yù-zhàng qiāo huā-piàn.

lightly take jade-stick tap flower-petal

'Taking a piece of jade, she lightly tapped on the flower petals.'

(Zhang Hu: Gong zi xing, 9th c., from Wang, Li 1958: Ch. 47: 539)

Like the synchronic studies on SVC, diachronic studies do not indicate which one among the numerous structures subsumed under the label SVC they refer to, but in general content themselves with providing the purely linear sequence 'V1 NP V2 (NP)'. 33

All researchers agree, following Zhu (1957), that the source structure for the modern $b \breve{a}$ construction is the object sharing pattern in (68), the instrumental patttern with $b \breve{a}$ as illustrated in (69) being lost in Modern Mandarin. Accordingly, as argued for in detail in Whitman and Paul (2005), two different structures must be postulated for (68) and (69) in order to account for the presence of object sharing in (68) and its absence in (69d). While (68) is to be analyzed in terms of an object sharing SVC à la Collins (1997) (cf. (70)), (71) illustrates an instrumental adjunct structure (cf. (71):

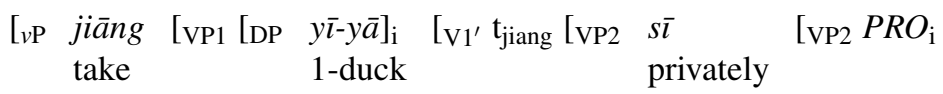

$$
\begin{aligned}
& \text { yòng]]]]] } \\
& \text { use } \\
& \text { 'grab a duck and use it for himself.' }
\end{aligned}
$$

$b \breve{a}$ does not assign a theta-role to the NP in its complement, another difference with respect to SVC, irrespective of their surface realization (as a 'V1 NP V2' sequence in Ewe or as a 'V1-V2' compound in $\neq$ Hoan).

32. Specialists in Chinese historical syntax generally treat bă and jiāng together, along with another 'take' verb, i.e., chí 'seize, hold' (Wang, Li 1958: Ch. 47; Zhu, Minche 1957; Peyraube 1996: 168).

33. If traditional analyses indicate any hierarchy between $b \breve{a}$ and the second verb at all, they assume it to be the same in both cases, (68) and (69). Peyraube (1985: 208) and Cui (1984) e.g., postulate a coordinate structure, while Zhu (1957) and Wang, Li (1958/88: Ch. 47) suggest a structure where V1 modifies V2, i.e., an adjunct structure. Likewise, Audrey Li (2006: 411) simply states that the source structure for the modern $b a ̆$ construction is a SVC, without indicating what structure she is referring to. 


$$
\begin{aligned}
& \text { [vP qīng [ [vP [adjunct clause PRO jiāng yù-zhàng] }{ }_{{ }_{\nu} \mathrm{P}} \text { qiāo } \\
& \text { lightly take jade-stick tap } \\
& \text { [vP2 } \mathrm{t}_{\text {qiao }} \text { huā-piàn]]] } \\
& \text { flower-petal } \\
& \text { 'taking a piece of jade, lightly tap on the flower petals' }
\end{aligned}
$$

In (70) jiāng 'seize, hold' selects the second VP headed by yòng 'use' as its complement. The shared object DP $y \bar{l}-y \bar{a}$ 'a duck' is merged in the specifier of the VP headed by jiāng and controls $P R O$ in the complement VP. In (71), by contrast, there is no control relation between the object of the verb in the adjoined $\mathrm{VP}_{1}$ and the object of $\mathrm{VP}_{2}$.

Importantly, jiāng occupies two different positions in (70) vs. (71): in the object sharing SVC (70), jiäng functions as the main verb, whereas in the adjunct structure (71), jiāng is contained in the adjunct clause which modifies the main VP, headed by qiāo 'tap'. This difference can be visualized using a maximal VP structure (72), where the main verb in an object sharing SVC is further modified by an adjunct clause. The main verb position occupied by jiāng in (70) corresponds to the $\mathrm{V}_{2}$ position in (72), while the adjoined position occupied by jiāng in (71) corresponds to $\mathrm{V}_{1}$ in (72):

$$
\begin{aligned}
& \text { [vP [adjunct clause } \left.\mathrm{PRO} \mathrm{VP}_{1}\right]\left[{ } _ { v \mathrm { P } } \mathrm { V } _ { 2 } \left[\mathrm { vP2 } \mathrm { DP } _ { \mathrm { i } } \left[\mathrm { v } ^ { \prime } \mathrm { t } _ { \mathrm { V } 2 } \left[\mathrm { vP } 3 P R O _ { \mathrm { i } } \left[\mathrm{v}^{\prime} \mathrm{V}_{3}\right.\right.\right.\right.\right. \\
& \mathrm{XP}]]]]]]
\end{aligned}
$$

If we now subject (72) to Whitman's (2000) conservancy of structure constraint according to which reanalysis must preserve hierarchical c-command relations and can only change categorial features and eliminate unmotivated structure, we obtain the following predictions. Verbs in the $\mathrm{VP}_{1}$ and $\mathrm{VP}_{3}$ positions may undergo $\mathrm{V}$-to-P reanalysis, because these may serve as positions for PPs. The main verb $\mathrm{V}_{2}$ having raised to $v$, on the other hand, is predicted not to be reanalyzable as a preposition, because the resultant structure would involve a change of c-command relations and be ill-formed: a preposition cannot support tense, nor is it selected by $v$. Given the general assumption (following Zhu 1957) that the source for the modern $b a \breve{~ c o n s t r u c t i o n ~ a r e ~ s e n t e n c e s ~ s u c h ~}$ as (68) which have been identified as an object sharing SVC with jiāng as the main verb $\left(V_{2}\right.$ in (72)), this implies that $b \breve{a}$ cannot have been reanalyzed as a preposition, contrary to traditional views.

While this result may be surprising at first sight, it ties in with the growing consensus that $b \breve{a}$ is not a preposition, but should be viewed as the head of a (functional) projection above $\nu \mathrm{P}$ (cf. Sybesma 1992, 1999; Zou 1993; Li 2006; Paul 2002b). On this view, $b \breve{a}$ continues to take the projection of the verb to its right as its complement and thus maintains previous hierarchical relations. The correctness of this analysis is clearly shown by the possibility of 
conjoining two occurrences of preverbal object plus VP under $b \breve{a}$ (cf. Wu 1982: 434):

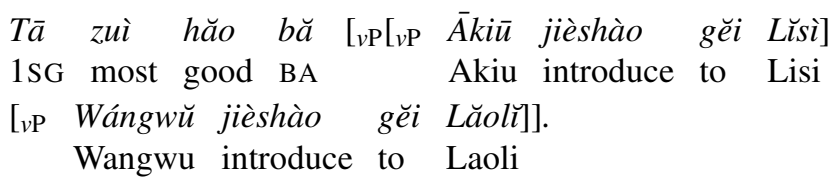

This fact would be difficult to explain if $b \breve{a}$ and the immediately following NP formed a constituent, as the prepositional analysis of $b \breve{a}$ holds. The behavior of $b \breve{a}$ in (73) contrasts sharply with (74), where a true PP is involved; (74)

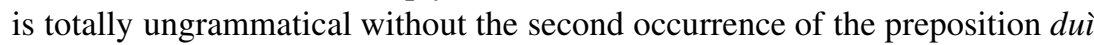
'towards'.

$$
\begin{aligned}
& \text { Wŏ zhīdao tā [PP duì Lüsì] hĕn yŏu yìjiàn, } \\
& 1 \mathrm{SG} \text { know } 3 \mathrm{SG} \text { towards Lisi very have prejudice } \\
& \text { [PP *(duì) Lăolı̆] yӗ hĕn yŏu yìjiàn. } \\
& \text { tow Laoli also very have prejudice }
\end{aligned}
$$

'I know that he is very prejudiced against Lisi, and also against Laoli.'

(For further arguments in favor of $b \breve{a}$ as a higher verbal head in modern Mandarin, cf. Whitman and Paul 2005.)

In contrast to $\mathrm{V}_{2}$ occupying the main verb position in an extended VP projection (72), verbs in either $\mathrm{V}_{1}$ or $\mathrm{V}_{3}$ position may be reanalyzed as prepositions, for reanalysis in these positions does not induce any change in the basic structure of the clause. V-to-P reanalyses in the adjunct $\left(\mathrm{V}_{1}\right)$ position are especially numerous: cóng 'follow $>$ from', gēn 'accompany $>$ with', duì 'face $>$ towards' etc.:

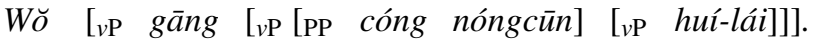

$$
\begin{aligned}
& 1 \mathrm{SG} \text { just from village return-come } \\
& \text { 'I have just come back from the village.' (Lü 2000: 130) }
\end{aligned}
$$

The basic configuration of the example (75) from Modern Mandarin, where cóng heads an adjunct projection preceding the main verb, is already attested in the Zuozhuan (cf. (76)):

$$
\begin{aligned}
& \text { Cóng tái-shang tán rén. } \\
& \text { from platform-upon shoot people } \\
& \text { 'He shot people from up on the platform.' } \\
& \text { (Zuozhuan: Xuangong 2; 5th c.-3rd c. BC). }
\end{aligned}
$$


The Zuozhuan also provides the source structure for V-to-P reanalysis where the verb cóng 'follow, pursue' is contained in an adjunct clause:

$$
\begin{aligned}
& \text { Xià [DP zhūhón zhi dàifü] [vP [adj.clause PRO } \\
& \text { summer feudal.lord SUB high.official } \\
& \text { cóng Jin hóu } \quad \text { [vP fá Qín]]. } \\
& \text { follow Jin duke attack Qin } \\
& \text { 'In summer, the high officials of the feudal lords, following the duke } \\
& \text { of Jin, attacked Qin.' } \\
& \text { (Zuozhuan: Xianggong 14; 5th c.-3rd c. BC) }
\end{aligned}
$$

This section has demonstrated that once we become aware of the current indeterminacy of the term SVC and give it an exact definition (e.g., as an object sharing structure à la Collins), we are led to two surprising conclusions. First, contrary to general assumptions, object sharing SVCs are not a privileged source structure for V-to-P reanalysis; instead, the primary historical source for prepositions derived from verbs in Chinese are adjunct clauses (V1 in (72)) (cf. Whitman and Paul 2005). Second, concerning the possible changes affecting an object sharing SVC, the main verb (V2 in (72)) is precisely excluded from Vto-P reanalysis, due to Whitman's (2000) conservancy of structure constraint. Consequently, $b \breve{a}$ - deriving from this main verb position - cannot be a preposition, but has the status of a higher verbal head. These results, which can only be obtained by adopting a rigorous definition of the term SVC, demonstrate that meaningful statements about language change presuppose a precise analysis of both the input and the output structure.

\subsection{SVCs in typology: Example of a "serialization parameter"}

In general, SVCs are said to be a typical property of languages lacking verbal inflectional morphology (such as, e.g., Chinese). However, a closer look at the languages with and without SVCs reveals this at first sight plausible generalisation to be wrong. English, e.g., is troublesome in this respect, because "although" it does not show any person/number agreement on the verb (the third person singular $-s$ being construable as a present tense marker), it does not have SVCs (but cf. Pullum 1990). In Yorùbá, by contrast, mood/tense is marked on the verb (cf. Stahlke 1970), and "nevertheless" it allows SVCs. Likewise, the Misumalpan languages Miskitu and Sumu have SVCs (cf. Salamanca 1988; Hale 1991), but display a rich inflectional morphology: the verb is not only marked for tense and person, but also for proximate (same subject) vs. obviative (different subject).

For Den Dikken and Sybesma (1998), the basic distinction between languages with and without SVC is that "[...] serialising languages differ from 
non-serialising ones such as English in their inability to spell out the $v-\mathrm{V}$ combination as one single lexical element [...]" (p. 1), i.e., in serializing languages $\mathrm{V}$ does not raise to $v$. They then introduce - without further comment - yet another definition of SVC as sequences ' $\mathrm{V}_{1} \mathrm{NP} \mathrm{V}_{2}$ ' where $\mathrm{V}_{1}$ does not assign a theta-role to NP. Under this definition, the object/internal argument sharing SVC from Ewe (cf. (49), (50)) - though representing one of the SVC core cases in Niger-Congo languages - would not count as SVC, the shared argument NP clearly receiving a theta-role from the first verb. With this caveat in mind, let us proceed to their next claim, namely that the modern Mandarin $b \breve{a}$-construction (cf. 78) is an SVC, with bă in $v$ :

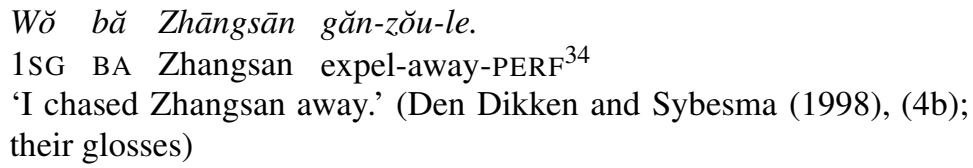

Furthermore, they postulate the following (interrelated) assumptions concerning the $b \breve{a}$-construction:

(79) a. The $b \breve{a}$-construction is only possible with a complex verb.

b. One component of this complex verb is non-verbal (noted as ' $\mathrm{X}$ ' in $(80 a-b))$.

c. This non-verbal component functions as the predicate of a small clause (SC), with the NP following $b \breve{a}$ as its subject.

Accordingly, (78) is assigned the structure and derivation in (80a-b):

$$
\begin{aligned}
& \text { a. [VP [v } g \breve{a n}] \quad\left[\mathrm{SC}[\mathrm{NP} \text { Zhāngsān }]\left[\begin{array}{ll}
\mathrm{x} & z \breve{o u}
\end{array}\right]\right] \\
& \text { expel Zhangsan away }
\end{aligned}
$$

(= Den Dikken and Sybesma's (17))

The "dummy" element $b \breve{a}$ is inserted into $v$ and the NP raises to Spec, FP between $v$ and $\mathrm{V}$ :

\footnotetext{
34. The item zŏu glossed as 'away' by den Dikken and Sybesma (1998) in fact is nothing else but the verb zŏu 'leave', whose verbal status is uncontested (also cf. (84) below):

(i) Tā zŏu-le

3SG leave-PERF

'She left.'

(ii) $\quad N \breve{l}$ shénmeshíhou yào zŏu?

$2 \mathrm{SG}$ when want leave

'When do you want to leave?'
} 


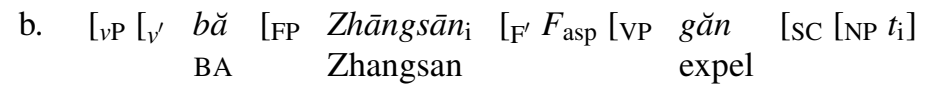

$$
\begin{aligned}
& \left.\left.\left.\left.\left.\left.\left[\begin{array}{ll}
\mathrm{x} & z \breve{o u}
\end{array}\right]\right]\right]\right]\right]\right]\right] \\
& \text { away } \\
& \text { 'chase Zhangsan away' }
\end{aligned}
$$

(80b) is the structure of a SVC proposed by den Dikken and Sybesma (1998): the verb does not raise to $v$ and $v$ is therefore lexicalized by an independent morpheme, in this case $b \breve{a}$, a process said to be typical of serializing languages. However, this analysis of the $b \breve{a}$ construction and the assumptions (79a-c) underlying it are not correct.

First of all, the $b \breve{a}$-construction is perfectly acceptable with simple verbs and not at all limited to complex verbs as claimed by Den Dikken and Sybesma (also cf. (66a) above) $:^{35}$

$$
\begin{aligned}
& \text { Tā bă Zhāngsān piàn-le. } \\
& \text { 3SG BA Zhangsan cheat-PERF } \\
& \text { 'She cheated Zhangsan.' }
\end{aligned}
$$

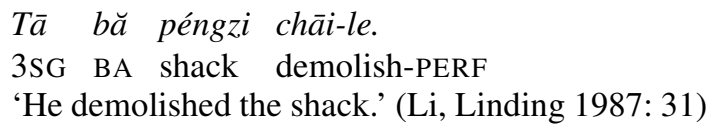

Accordingly, there is no non-verbal element $\mathrm{X}$ available to function as the predicate of the small clause, hence no reason to postulate a small clause at all.

Furthermore, the statement in (79b) that one component of the complex verb is non-verbal is equally wrong. Resultative verb compounds such as $g a ̆ n-z \breve{o u}$ 'chase-leave' = 'chase away', chī-wán 'eat-finish' = 'eat up', etc. are in general analyzed as consisting of two verbal elements, each maintaining its thematical grid (cf., among others, Chao 1968: Section 6.6.2-3; Li and Thompson 1981, 3.2.3; Yafei Li 1993). Examples (84) and (86) below demonstrate that the second component in a verb compound can clearly function as a verb on its own:

$$
\begin{aligned}
& \text { Wŏ bă Zhāngsān }\left[\mathrm{v}^{\circ}\right. \text { găn-zŏu]-le. } \\
& 1 \mathrm{SG} \text { BA Zhangsan expel-leave-PERF } \\
& \text { 'I chased Zhangsan away.' (=(78) above, with my glosses) }
\end{aligned}
$$

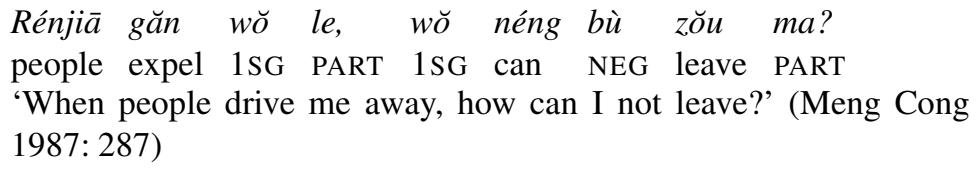




$$
\text { Tā kàn-wán-le / chī-wán-le / fùxí-wán-le. }
$$

3SG read finish-PERF / eat finish-PERF / revise-finish-PERF 'He has finished reading/eating/revising.'

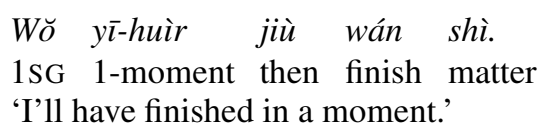

Once the verbal status of the second element in verbal compounds ' $\mathrm{V}_{1}-\mathrm{V}_{2}$ ' acknowledged, Den Dikken and Sybesma's (1998) postulate of a small clause (with the alleged non-verbal element $\mathrm{X}$ as predicate) is further invalidated.

Last, but not least, it is not correct to locate $b \breve{a}$ in small $v$ and the verb in VP (an analysis equally rejected by Audrey Li 2006). Instead, the verb itself raises to $v$ (and eventually on to Asp), as evidenced by the possibility of adjoining manner and other VP-level adverbs below $b \breve{a} .{ }^{36}$ The higher verbal head $b \breve{a}$ must therefore select a $v \mathrm{P}$ (or AspP) as complement (cf. Paul 2002b; Whitman and Paul 2005):

$$
\begin{aligned}
& \text { Tā } \quad\left[v \mathrm { P } \quad b \breve { a } \quad \left[\mathrm{BaP} \text { Zhāngsān } t_{\mathrm{ba}}[\mathrm{AspP} \text { hĕnxīnde [AspP }\right.\right. \\
& \text { pāoqì-le } \quad\left[{ }_{\nu \mathrm{P}}\left[\mathrm{vP} t_{\mathrm{V}} t_{\text {Zhangsan }}\right]\right]
\end{aligned}
$$

(slightly changed example from Tang 1990: 145; (111); bracketing mine)

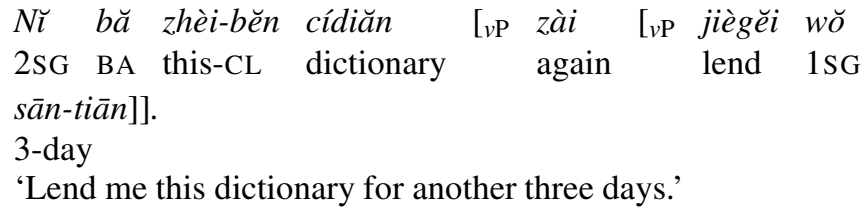

The examples (87)-(88) also demonstrate that the $b \breve{a}$ construction in Modern Mandarin does not instantiate an object sharing SVC. Bă no longer assigns a thematic role to a complement DP; instead, the DP in the specifier of $b \breve{a}$, e.g., Zhangsan in (87), moves to that position. Furthermore, the distribution of VP-level adverbs show that $b \breve{a}$ originates in a head position higher than 
lexical verbs (i.e., higher than $v \mathrm{P}$ or AspP, respectively), from where it moves on to (the highest) $v .^{37}$

As demonstrated in detail above, Den Dikken and Sybesma's (1998) analysis of the $b \breve{a}$ construction is not viable; in particular, the verb does raise to $v$ here, as elsewhere in the syntax of Chinese (cf. a.o. Huang 1991, 1992). Consequently, the $b \breve{a}$ construction does not comply with Den Dikken and Sybesma's (1998) definition of SVC, for which the lack of V-to- $v$ movement is crucial. At the same time, this also sheds doubt on the general typological difference between serializing and non-serializing languages which they derive from their incorrect analysis of the $b \breve{a}$ construction: while serializing languages are said to be characterized by the lack of V-to- $v$ movement, correlated with the existence of an independent 'take' element able to lexicalize $v$, this is claimed not to be the case for non-serializing languages where $\mathrm{V}$ raises to $v$.

To conclude, Den Dikken and Sybesma (1998) once again illustrates the rather arbitrary content which can be ascribed to the term SVC, due to the coexistence of diverging conceptions. Their article equally shows how the failure to realize the problematic status of SVC may give rise to questionable typological generalizations. ${ }^{38}$

\section{Conclusion}

Examining in detail the coverage of the term serial verb construction in Chinese linguistics, I have argued that in order to talk of a construction, a precise structural analysis and a predictable set of formal properties associated with

37. The structure assigned to the Modern Mandarin bă construction by Whitman and Paul (2005) (cf. (87)) is thus different from that proposed by Li, Y.A. (2006: 412):

(i) $\quad\left[\mathrm{BaP}\left[\mathrm{Ba}^{\prime} b \breve{a}\left[{ }_{v \mathrm{P}} \mathrm{NP}\left[v^{\prime}[\mathrm{V}[\mathrm{vP}\right.\right.\right.\right.$ tv XP]]]]]]

$B \breve{a}$ as the head of $\mathrm{BaP}$ stays in situ and takes a $v \mathrm{P}$ complement with the direct object in its specifier; on this view, adverbs to the right of bă such as hěnxīnde 'heartless' in (87) must be adjoined to $v$, a rather implausible assumption.

38. The same lack of awareness with respect to the problematic character of the term SVC can also be observed in studies on grammaticalization. For instance, Roberts and Roussou (2003) postulate (i) as the approximate structure for a SVC:

(i) $\quad\left[\mathrm{cP} \mathrm{C}\left[\mathrm{TP} \mathrm{T}\left[\mathrm{vP1} \mathrm{V}_{1}\left[\mathrm{vP2} \mathrm{V}_{2}\right]\right]\right]\right]$

(= Roberts and Roussou 2003: 126 (90a))

They state that an SVC involves two (or more) VPs expressing a single event, evoke the possibility for $\mathrm{V} 1$ and $\mathrm{V} 2$ to be in a complementation relation or a paratactic relation, and refer to Baker (1989); Lefebvre (1991); Collins (1993); Déchaine (1993); and Den Dikken and Sybesma (1998) for further details. Apparently, they are unaware that the cited references postulate different and sometimes even opposing structures for SVCs and can therefore not help fleshing out the details left open in structure (i). 
that structure must be provided. I have chosen the SVC because it plays quite an important role in Chinese linguistics and elsewhere, especially in diachronic studies where it is presented as the privileged site for grammaticalization processes. Likewise, in synchronic linguistics, the SVC is appealed to as a kind of deus ex machina whenever a sentence containing two or more verbs is difficult to analyze.

Against this common trend, I have argued that the SVC, as it is currently understood, has no theoretical status in the grammar of Mandarin Chinese i.e., it does not represent a unique construction associated with a precise structure and a predictable set of syntactic and semantic properties (though there are evidently sentences containing more than one verb in Chinese). Instead, the phenomena subsumed under the one label SVC in fact turn out to represent separate constructions with completely different properties. The term SVC should therefore be abandoned in Chinese linguistics, at least for the structures subsumed so far under this label.

In the studies of Niger-Congo languages, the so-called SVC are also a much discussed phenomenon. Even though the consensus here is somewhat greater as to which structure should be subsumed under the term SVC and which not, we nevertheless face a situation similar to that in Chinese linguistics. That is, when confronted with the term SVC, we do not know which construction is referred to. This problem linked to the indeterminacy of the term SVC increases exponentially in crosslinguistic comparison when, e.g., SVC in Chinese are compared with SVC in Niger-Congo languages. In such a case, it is not clear at all to what extent the phenomena covered by the term SVC in each language overlap, nor whether they overlap at all.

Unfortunately, this problematic status of SVC has not been paid any attention to in the literature. On the contrary, reference is made from SVCs in Chinese to those in Niger-Congo languages and vice versa as though one and the same phenomenon was involved (cf. Lefebvre 1991; Lord 1973; Collins 2002). Furthermore, important theoretical conclusions in terms of a typologically relevant "serialization parameter" (cf. Larson 1991; Den Dikken and Sybesma 1998; Stewart 2001, among others) distinguishing so-called "serializing" from so-called "non-serializing" languages have been drawn on the basis of incommensurable phenomena. Ultimately, it is hoped that a strict definition of the term SVC may lead to a more realistic appraisal of the dichotomy "serializing" vs. "non-serializing" languages and its place in typological studies. 


\section{References}

Aikhenvald, Alexandra Y. and Robert M.W. Dixon (eds.) (2006). Serial Verb Constructions. A Cross-Linguistic Typology. Oxford: Oxford University Press.

Baker, Mark (1989). Object sharing in serial verb constructions. Linguistic Inquiry 20: 513-553.

Baker, Mark and Osamuyimen T. Stewart (2002). A serial verb construction without constructions. Ms., Rutgers University. http://lang.rutgers.edu/people/faculty/baker/SVCarch-ss.pdf.

Bisang, Walter (1992). Das Verb im Chinesischen, Hmong, Vietnamesischen, Thai and Khmer. Vergleichende Grammatik im Rahmen der Verbserialisierung, der Grammatikalisierung und der Attraktorpositionen. [Language Universals Series, 7]. Tübingen: Narr.

Chan, Stephen W. (1974). Asymmetry in temporal and sequential clauses in Chinese. Journal of Chinese Linguistics 2: 340-353.

Chang, Hsun-Huei Claire (1991). Interactions between syntax and morphology: A case study of Mandarin Chinese. Ph.D. Dissertation, University of Hawaii.

Chao, Yuen Ren (1948). Mandarin Primer. Cambridge, MA: Harvard University Press

Chao, Yuen Ren (1968). A Grammar of spoken Chinese. Los Angeles: University of California Press.

Chen, Xilong. (1993). On the syntax of serial verb constructions in Chinese. Ph.D. Dissertation, University of Georgia.

Chomsky, Noam (1980). On binding. Linguistic Inquiry 11: 1-46.

Collins, Chris (1993). Topics in Ewe syntax. Ph.D. Dissertation, MIT, Cambridge.

Collins, Chris (1997). Argument sharing in serial verb constructions. Linguistic Inquiry 28: 461497.

Collins, Chris (2002). Multiple verb movement in $\neq$ Hoan. Linguistic Inquiry 33: 1-29.

Cui, Gui-bo (1984). Zhuzi yulei de suo biaoxain de ji-ge baihua yufa xianxiang [Some grammatical phenomena of the vernacular language in the Zhuzi yulei]. Master's thesis, National Taiwan University.

Déchaine, Rose-Marie (1986). Opérations sur les structures d'argument: le cas des constructions sérielles en haïtien. Master's thesis, Université du Québec à Montréal.

Déchaine, Rose-Marie (1993). Serial verb constructions. In Syntax. An International Handbook of Contemporary Research, vol. 1, Joachim Jacobs, Arnim von Stechow, Wolfgang Sternefeld and Theo Vennemann (eds.), 799-825. Berlin: de Gruyter.

Den Dikken, Marcel and Rint Sybesma (1998). Take serials light up the middle. Paper presented at the 20th GLOW Colloquim, Tilburg, 15th April 1998.

Ernst, Thomas (1989). On verb subcategorization in Chinese. In Proceedings of the Third Ohio State University Conference on Chinese Linguistics, Marjorie Chan and Thomas Ernst (eds.), 116-140. Bloomington, Indiana: Indiana University Linguistics Club.

Ernst, Thomas (1994). Functional categories and the Chinese Infl. Linguistics 32: 191-212.

Ernst, Thomas and Chengchi Wang (1995). Object preposing in Mandarin Chinese. Journal of East Asian Linguistics 4: 235-260.

Fan, Jiyan (1963). Dòngcí hé q_xiàng xìng hòuzhì chéng fēn de jiégòu fēnxī [Analysis of the structure verb plus directional complement]. Zhongguo Yuwen 2: 136-160.

Foley, William A. and Mike Olson (1985). Clausehood and serialization. In Grammar Inside and Outside the Clause, Johanna Nichols and Anthony Woodbury (eds.), 17-60. Cambridge: Cambridge University Press.

Gasde, Horst-Dieter and Waltraud Paul (1996). Functional categories, topic prominence, and complex sentences in Mandarin Chinese. Linguistics 34: 263-294.

Georgala, Effi, Waltraud Paul and John Whitman (2007). Expletive and thematic applicatives. Paper presented at the 26th West Coast Conference on Formal Linguistics, University of California at Berkeley, April 27-29, 2007.

Hale, Ken (1991). Misumalpan verb sequencing constructions. In Serial Verbs: Grammatical, Comparative and Cognitive Approaches, Claire Lefebvre (ed.), 1-35. Amsterdam: Benjamins. 
Huang, C.-T. James (1981/82). Move $w h$ in a language without wh movement. The Linguistic Review 1: 369-416.

Huang, C.-T. James (1982). Logical relations in Chinese and the theory of grammar. Ph.D. Dissertation, MIT, Cambridge.

Huang, C.-T. James (1984a). On the distribution and reference of empty pronouns. Linguistic Inquiry 15: 531-574.

Huang, C.-T. James (1984b). Phrase structure, lexical integrity and Chinese compounds. Journal of the Chinese Language Teachers' Association 19: 53-48.

Huang, C.-T. James (1987). Existential sentences in Chinese and (In)definiteness. In The Representation of (In)definiteness, Eric J. Reuland and Alice G.B. ter Meulen (eds.), 226-253. Cambridge, MA: MIT Press.

Huang, C.-T. James (1991). Verb movement, (in)definiteness, and the thematic hierarchy. Proceedings of the Second International Symposium of Chinese Languages and Linguistics, 481-498. Taipei: Academia Sinica

Huang, C.-T. James (1992). On lexical structure and syntactic projection. Proceedings of the Third International Symposium of Chinese Languages and Linguistics, 288-311. Taipei: Academia Sinica.

Kimura, Hideki. 1984. On two functions of the directional complements lái and qù in Mandarin. Journal of Chinese Linguistics 12: 262-297.

Larson, Richard (1991). Some issues in verb serialization. In Serial Verbs: Grammatical, Comparative and Cognitive approaches. Claire Lefebvre (ed.), 185-210. Amsterdam: Benjamins.

Law, Paul (1996). A note on the serial verb construction in Chinese. Cahiers de Linguistique - Asie orientale 25: 199 -235.

Law, Paul and Tonjes Veenstra (1992). On the structure of serial verb constructions. Linguistic Analysis 22: 185-217.

Lee, Thomas Hun-Tak (1996). Theoretical issues in language development and Chinese child language. In New Horizons in Chinese linguistics, C.-T. James Huang and Y.-H. Audrey Li (eds.), 293-356. Dordrecht: Kluwer.

Lefebvre, Claire (ed.) (1991). Serial Verbs: Grammatical, Comparative and Cognitive Approaches. Amsterdam: Benjamins.

Li, Charles and Sandra A. Thompson (1973). Serial verb constructions in Mandarin Chinese: Subordination or coordination? In You Take the High Node and I'll take the Low Node: Papers from the Comparative Syntax Festival, C. Corum, T.C. Smith-Stark and A. Weiser (eds.), 96-103. Chicago: Chicago Linguistic Society.

Li, Charles and Sandra A. Thompson (1974a). Coverbs in Mandarin Chinese: Verbs or prepositions? Journal of Chinese Linguistics 2: 257-278.

Li, Charles and Sandra A. Thompson (1974b). An explanation of word order change: SVO > SOV. Foundations of Language 12: 201-214.

Li, Charles and Sandra A. Thompson (1981). Mandarin Chinese. A Functional Reference Grammar. Berkeley: University of California Press.

Li, Linding (1984). Dòngcí de bīnyŭ hé jiégòu de bīnyŭ [The object of a verb and the object of a verbal construction]. Yŭyán Jiāoxué yŭ Yánjiū 3: 103-114.

Li, Linding (1986). Xiàndài hànyŭ jùxíng [Sentence patterns in Modern Mandarin]. Beijing: Shanggwu yinshuguan.

Li, Linding (1987). Xiàndài hànyŭ yŭfă de tèdiăn [Grammatical characteristics of Modern Chinese]. Beijing: Renmin jiaoyu chubanshe.

Li, Y.-H. Audrey (1985). Abstract case in Chinese. Ph.D. Dissertation, University of Southern California, Los Angeles.

Li, Y.-H. Audrey (1990). Order and Constituency in Mandarin Chinese. Dordrecht: Kluwer.

Li, Y.-H. Audrey (2006). Chinese Ba. In The Blackwell Companion to Syntax, vol. 1, Martin Everaert and Henk van Rimesdijk (eds.), 374-468. Oxford: Blackwell. 
Li, Yafei (1991). On deriving serial verb constructions. In Serial Verbs: Grammatical, Comparative and Cognitive Approaches, Claire Lefebvre (ed.), 103-135. Amsterdam: Benjamins.

Li, Yafei (1993). Structural heads and aspectuality. Language 69: 480-504.

Lin, Tzong-Hong Jonah (2001). Light verb syntax and the theory of phrase structure. Ph.D. Dissertation, University of California, Irvine.

Liu Yuehua (1988). Qūxiàng bŭyŭ de yŭfă yìyì [The grammatical meaning of directional complements]. Yŭfă Yánjiū hé Tànsuŏ 6: 74-88.

Lord, Carol (1973). Serial verbs in transition. Studies in African Linguistics 4: 269-296.

Lu, Jianming (1985). Guānyú 'qù + VP' hé 'VP + qù' jùshì [On the 'go + VP' and the 'VP + go' pattern]. Yŭyán Jiā̄xué yŭ Yánjīu 4: 18-32.

Lu, John H.-T. (1973). The verb-verb constructions with a directional complement in Mandarin. Journal of Chinese Linguistics 1: 239-255.

Lü, Shuxiang (ed.) (2000). Xiàndài hànyŭ bābăi cí [800 words of Modern Chinese]. Beijing: Shangwu yinshuguan.

Matthews, Stephen (2006). On serial verb constructions in Cantonese. In Serial Verb Constructions. A Cross-Linguistic Typology, Alexandra Y. Aikhenvald and Robert M.W. Dixon (eds.), 69-87. Oxford: Oxford University Press.

Mei, Tsu-lin (1981). Xiandai hanyu wancheng mao jushi he ci de laiyuan [The origin of the perfective aspect construction and the perfective suffix in Modern Chinese]. Yuyan yanjiu 1, 65-77.

Meng Cong (ed). (1987). Dongci yongfa cidian [A practical dictionary of verbs]. Shanghai: Cishu chubanshe.

Muysken, Pieter and Tonjes Veenstra (2006). Serial verbs. In The Blackwell Companion to Syntax, vol. 4, Martin Everaert and Henk van Riemsdijk (eds.), 234-270. Oxford: Blackwell.

Paul, Waltraud (2002a). Sentence-internal topics in Mandarin Chinese: The case of object preposing. Language and Linguistics 3: 695-714.

Paul, Waltraud (2002b). Proxy categories in phrase structure theory and the Chinese VP. Cahiers de Linguistique Asie Orientale 31: 137-174.

Paul, Waltraud (2005a). Adjectival modification in Mandarin Chinese and related issues. Linguistics 43: 757-793.

Paul, Waltraud (2005b). Low IP area and left periphery in Mandarin Chinese. Recherches Linguistiques de Vincennes 33: 111-134.

Paul, Waltraud (in preparation). Directional verb "compounds" revisited. MS, CRLAO, Paris.

Peyraube, Alain (1985). Les structures en ba en chinois mediéval et moderne. Cahiers de Linguistique - Asie Orientale 14: 193-213.

Peyraube, Alain (1996). Recent issues in Chinese historical syntax. In New Horizons in Chinese Linguistics, C.-T. James Huang and Y.-H. Audrey Li (eds.), 161-213. Dordrecht: Kluwer.

Pullum, Geoffrey K. (1990). Constraints on intransitive quasi serial-verb constructions in modern colloquial English. In When Verbs Collide: Papers from the Ohio State Mini-Conference on Serial Verbs. Ohio State University Working Papers in Linguistics 39, Brian D. Joseph and Arnold M. Zwicky (eds.), 218-239. Ohio: Ohio State University.

Richards, Norvin (1997). What moves where when in which language? Ph.D. Dissertation, MIT, Cambridge.

Roberts, Ian and Anna Roussou (2003). Syntactic Change. A Minimalist Approach to Gramaticalization. Cambridge: Cambridge University Press.

Ross, Claudia (1991). Coverbs and category distinctions in Mandarin Chinese. Journal of Chinese Linguistics 19: 79-114.

Safir, Ken (1982). Syntactic chains and the definiteness effect. Ph.D. Dissertation, MIT, Cambridge.

Salamanca, Danilo (1988). Elementos de Gramaticà del Miskitu. Ph.D. Disssertation, MIT, Cambridge.

Simpson, Andrew and Zoe Wu (2002). IP raising, tone sandhi and the creation of S-final particles: evidence for cyclic spell-out. Journal of East Asian Linguistics 11: 67-99. 
Soh, Hooi-Ling (1998). Object scrambling in Chinese. Ph.D. Dissertation, MIT, Cambridge. Stahlke, Herbert (1970). Serial verbs. Studies in African Linguistics 1: 60-99.

Stewart, Osamuyimen T. (1996). Adverb placement and the structure of the serial verb construction. Proceedings of the Twenty-sixth Meeting of the North East Linguistic Society, Kiyomi Kusumoto (ed.), 409-422. Amherst, MA: GLSA

Stewart, Osamuyimen T. (2001). The Serial Verb Construction Parameter. New York and London: Garland.

Sybesma, Rint (1992). Causatives and accomplishments. The case of Chinese ba. Ph.D. Dissertation, Leiden University.

Sybesma, Rint (1999). The Mandarin VP. Dordrecht: Kluwer.

Tang, Chih-Chen Jane (1990). Chinese phrase structure and the extended X-bar theory. Ph.D. Dissertation, Cornell University, Ithaca.

Tang, Ting-chi (2000). Hanyu de xianding ziju yu fei-xianding ziju [Finite and nonfinite clauses in Chinese]. Language and Linguistics 1: 191-217.

Teng, Shou-Hsin (1974). Negation in Chinese. Journal of Chinese Linguistics 2: 125-140.

Tsai, Wei-Tien Dylan (1994). On economizing the theory of A-bar dependencies. Ph.D. Dissertation, MIT, Cambridge.

Tsai, Wei-Tien Dylan (1995). Visibility, complement selection and the case requirement of CP. Journal of East Asian Linguistics 4: 281-312.

Wang, Li (1958). Hànyŭ shŭ găo (zhōng) [Outline of the history of Chinese, vol. 2]. Beijing: Kexue chubanshe. (reprinted in: Wang, Li (1988). Wáng Lì wénjí [Collected works of Wang Li], vol. 9.).

Whitman, John (2000). Relabelling. In Diachronic Syntax: Models and Mechanisms, Susan Pintzuk, George Tsoulas and Anthony Warner (eds.), 220-238. Oxford: Oxford University Press.

Whitman, John and Waltraud Paul (2005). Reanalysis and conservancy of structure in Chinese. In Grammaticalization and Parametric Change, Montserrat Batllori, Maria-Lluïsa Hernanz; Carme Picallo and Francesc Roca (eds.), 82-94. Oxford: Oxford University Press.

Wippermann, Dorothea (1993). Liandongshi. Der Begriff der Verbalserie in der chinesischen Linguistik. Heidelberg: Julius Groos.

Wu, Meng (1982). Ba zi yongfa er li [Two illustrations for the usage of ba]. Zhongguo Yuwen 6: 434.

Xing, Janet (2003). Grammaticalization of verbs in Mandarin Chinese. Journal of Chinese Linguistics 31: 101-143.

Yang, Defeng (2004). 20 shìjì 80 niándài zhōng qí yilái de dòng-qū-shì yánjiū shùpíng [Research on directional complements since the middle of the 1980s]. Yüyán Jiāoxué yŭ Yánjiū 2: 5462.

Zhang, Shi (1990). Correlation between the double object construction and preposition stranding. Linguistic Inquiry 21: 312-316.

Zhu, Dexi (1982). Yufa jiangyi [Lectures on Chinese grammar]. Beijing: Shangwu yinshuguan.

Zhu, Minche (1957). Lun chuqi chuzhi shi [On the early disposal form]. Yuyanxue Luncong 1: $17-33$.

Zou, Ke (1993). The syntax of the Chinese ba construction. Linguistics 31: 715-36.

Zou, Ke (1994). Directional verb-compounds in Chinese. In Proceedings of the 30th Annual meeting of the Chicago Linguistic Society, Katherine Beals et al. (eds), vol. 1: 443-457. Chicago: Chicago Linguistic Society. 